Article

\title{
Conflicting Values in Rural Planning: A Multifunctionality Approach through Social Multi-Criteria Evaluation
}

\author{
Iker Etxano 1,2,3 (iD), Itziar Barinaga-Rementeria ${ }^{4, *}$ and Oihana Garcia 5 \\ 1 Department of Applied Economics I, University of the Basque Country (UPV/EHU), \\ 48940 Leioa, Spain; iker.etxano@ehu.eus \\ 2 HEGOA, Institute for International Cooperation and Development Studies, \\ University of the Basque Country (UPV/EHU), 48015 Bilbao, Spain \\ 3 EKOPOL, Research Group on Ecological Economics and Political Ecology, \\ University of the Basque Country (UPV/EHU), 48015 Bilbao, Spain \\ 4 Department of Accounting and Finance, University of the Basque Country (UPV/EHU), \\ 01006 Vitoria-Gasteiz, Spain \\ 5 Department of Applied Economics I, University of the Basque Country (UPV/EHU), \\ 01006 Vitoria-Gasteiz, Spain; oihana.garcia@ehu.eus \\ * Correspondence: itziar.barinagarementeria@ehu.eus; Tel.: +34-945-01-4372
}

Received: 28 March 2018; Accepted: 2 May 2018; Published: 4 May 2018

\begin{abstract}
The planning of rural land depends, to a large extent, on the agreed-upon agrarian and forestry development model. Within the framework of agrarian multifunctionality, to evaluate different development alternatives and their effect on territorial planning, its multiple dimensions must be considered as well as the interests and needs of the stakeholders. This work thus addresses the comprehensive evaluation of development alternatives for the rural area of a municipality of the Basque Country (Spain) through the implementation of a multi-criteria evaluation method with social participation. The results show, firstly, the existence of trade-offs between the functions to be promoted in the various development models evaluated. Secondly, the results indicate the need to reverse recent trends in the sector and the convenience of moving towards an agro-livestock model of greater ecological and local character, independently of the followed forest model. In fact, the evaluation carried out also reveals, thirdly, the existence of more or less latent conflicts, in particular with regards to forest policy.
\end{abstract}

Keywords: rural development; multifunctionality; rural planning; participatory process; social multi-criteria evaluation (SMCE)

\section{Introduction}

The rural word encompasses a complex system in which agro-ecological, economic and political aspects interact in a dynamic way. Traditionally used for agrarian purposes, European rural land has undergone major reshaping in recent decades, due to such factors as growing market globalization, new demands for environmental protection, changes in the agrarian and non-agrarian policies and pressures of urbanization and industrialization [1-4]. The emerged dynamics have provoked a loss of importance of the provision of agricultural commodities in comparison with the new demands and perspectives the society places on the rural world. Rural spaces are no longer valued solely for their status as suppliers of agricultural products; they also offer different public goods and services, not directly valuable in the markets and often in conflict with each other. 
In addition to the agrarian function, rural spaces offer fundamental environmental services [5]. Forests, for example, have gone from being mere wood producers to becoming important elements in the landscape, maintaining biodiversity and regulating the hydrological cycle [6,7]. On the other hand, social aspects such as the possibilities for leisure or the cultural value provided by rural spaces are also increasingly relevant in our society [8-10]. This shows, in turn, a change in social perception about the rural environment, recognizing the important role of rural spaces and agricultural activities in the conservation of the environment and its impact on human well-being [11], as well as the value of agricultural products, relating them with the quality and well-being of rural areas [12]. This new social perception also values farmers for their role as producers and promoters of rural areas [13-16]. In fact, the non-commodity services provided by agriculture are often a critical resource for the well-being of rural areas. Although these services cannot be directly valued by markets, they are enabling the diversification and maintenance of some rural economies by promoting tourist and recreational activities [17,18].

The concept of agricultural multifunctionality refers to this diversity of goods and services of an ecological, landscape, social and cultural nature provided by agricultural and forestry activities and rural areas as a whole. Multifunctionality emerged at the end of the 1990s within the European Union (EU) as a paradigm that responded to the transformation of European rural spaces [19] and, soon after, it extended to all industrialized countries [20]. Multifunctionality has been contemplated in European rural development policies since the agrarian reform proposed in Agenda 2000 [21], enabling rural development in the EU to gradually evolve from a sectoral approach focused on agriculture towards a more integrated vision, which also includes a vast vector of non-agrarian sectors and stakeholders [12,21]. Under the so-called second pillar of the Common Agricultural Policy (CAP), rural development policies have adopted an intersectoral approach and a more territory-oriented vision, paying attention to the relevance of ecological, social and cultural services that produce both agrarian and forest ecosystems [21,22].

This integrated vision of rural territory has been complemented, in turn, by two main territorial approaches and scales. On the one hand, the local scale has gained prominence in the socio-economic dynamization of rural areas, for example, through the LEADER approach. On the other hand, the EU has promoted all across Europe a policy of conservation of the environment basically in accordance with the development of the Natura 2000 network. Thus, the planning of rural spaces should be oriented to integrate and make compatible this amalgam of intersectoral objectives dependent on different territorial scales [23].

In practice, however, it is not an easy task to achieve the numerous objectives facing agricultural multifunctionality as a whole. The interactions between the goods and services provided by rural areas are complex due to the trade-offs between them. Thus, the fact that the demand for multifunctionality is diffuse may lead to an insufficient provision of certain goods and services derived from agricultural activity, such as those related to the conservation of the environment [24]. Also, given that rural land is a limited resource, it may be that public policies enhance certain functions to the detriment of others according to the development model chosen for it [25]. For example, the last reforms of the CAP aimed to enhance the environmental services of agriculture through decoupling subsidies from production and linking them to environmental preservation. Nevertheless, Spain opted to design measures that depend substantially on the historical status quo of agricultural holdings, and therefore the reforms have not led to significant changes in this country in terms of level of transfer, territorial distribution and environmental services supported [26,27]. It is not surprising therefore that the various functions attributed to rural spaces are in conflict, particularly in the field of territorial planning $[25,28]$. In fact, the stakeholders of the rural world hold visions, often opposed to each other, which can lead to these disagreements [29].

Indeed, the need to involve the local community in the management of natural resources is widely recognized [30-33], with the participation of the stakeholders involved being one of the pillars of good governance $[16,34]$. The involvement of the population and bottom-up participatory processes 
constitute an indispensable condition for the planning and development of rural territories [35-38]. In the evaluation of rural development models, therefore, the various functions in dispute should be considered in a comprehensive manner and with a holistic vision [39], through the use of interdisciplinary methods of evaluating alternatives, which also integrate the information and interests of the different stakeholders. The local scale is likewise considered adequate for the effective development of participatory processes when establishing the basis for rural development policies and the subsequent planning of rural land.

In this context, this work deals with the integral evaluation of rural development alternatives and their impact on land management through the implementation of a multi-criteria evaluation method with social participation. The evaluation has been carried out in the municipality of Mutriku (Basque Country, Spain) in collaboration with the local government and is framed in the work preceding the approval of the Municipal Land-Use Plan (MLUP). In the following section, we will look at the use of the selected methodology and detail the characteristics of the case study. The third section addresses the participatory process developed and the fourth describes the evaluation carried out. The results obtained are later discussed together with the conclusions reached.

\section{Methodological Framework and Site Description}

\subsection{Rural Planning through the SMCE}

Multi-criteria evaluation is a methodology with a long tradition in territorial planning (for example, [40]). In a given problem, the different possibilities of action (alternatives) are evaluated by considering certain relevant aspects (criteria). It has been emphasized, however, that in the decision-making processes, the structuring of the problem is at least as important as the technical evaluation of the alternatives considered [41]. In fact, territorial planning is strongly conditioned both by the complex values that underlie its approach and process [42] as well as by the uncertainty associated with it [43].

Under this prism, Social Multi-Criteria Evaluation (SMCE) is a tool to help decision-making processes in complex socio-ecological contexts. The bases and methodological foundations of the SMCE are distinguished by incorporating the incommensurability of values [44,45]. In accordance with the principle of weak comparability, the absence of a common unit of measure between plural values facilitates the incorporation of the values in dispute [46]. Thus, the SMCE is characterized by introducing an integrative and participatory perspective aimed at facilitating the search for solutions in complex situations such as those related to the management of natural resources or territorial planning.

Accordingly, the choice of the SMCE as a methodological framework for rural planning rests on four main arguments:

1. Territorial planning and management is by definition an area that incorporates a transdisciplinary vision of the territory, including different dimensions such as economic, social, landscape, ecological and institutional converge [47]. The SMCE avoids reductionism and confronts technical incommensurability $[44,45]$ by assumptions about the purpose of the model, the scale of analysis, and the establishment of dimensions, objectives, and criteria used in the evaluation process. It also allows the consideration of both quantitative and qualitative information by use of fuzzy set theory.

2. The different views that the stakeholders involved hold about the development models inherent in planning [48] highlight the existence of social incommensurability [44,45]. The SMCE incorporates these legitimate values, though contrasting in many cases, existing in society, through public participation.

3. Given its flexibility, the SMCE allows for the combination and integration of different methodologies and territorial analytical instruments [49]. For example, the SMCE allows for the integration of the use of Geographic Information Systems (GIS), an indispensable tool for the cartographic visualization of planning [50]. 
4. It should be noted that the SMCE is a robust method, whose usefulness and applicability has been demonstrated in the many real cases in which it has been applied. Among these cases, there are works carried out both in the field of territorial planning [50-53] as well as in the agrarian and forestry sector [54-57], the two areas on which our case study is focused.

Building upon previous approaches [45,58], the evaluation process developed in the planning of the rural area of Mutriku comprises five phases (Figure 1): (1) institutional analysis, in which the problem is defined and the stakeholders involved are identified; (2) selection of the evaluation criteria, to determine through which indicators the evaluation will be carried out; (3) definition of the alternatives; (4) complete the Multi-Criteria Impact Matrix (MCIM) and choose the aggregation method, to evaluate the alternatives and obtain their ranking; (5) sensitivity analysis and conflict analysis, to check whether the results are robust both technically and socially. All these phases have involved the participation of the stakeholders and have been developed in an iterative manner, thus allowing their feedback in terms of information and decision making throughout the process.

\section{Social Multi-Criteria Evaluation (SMCE):}

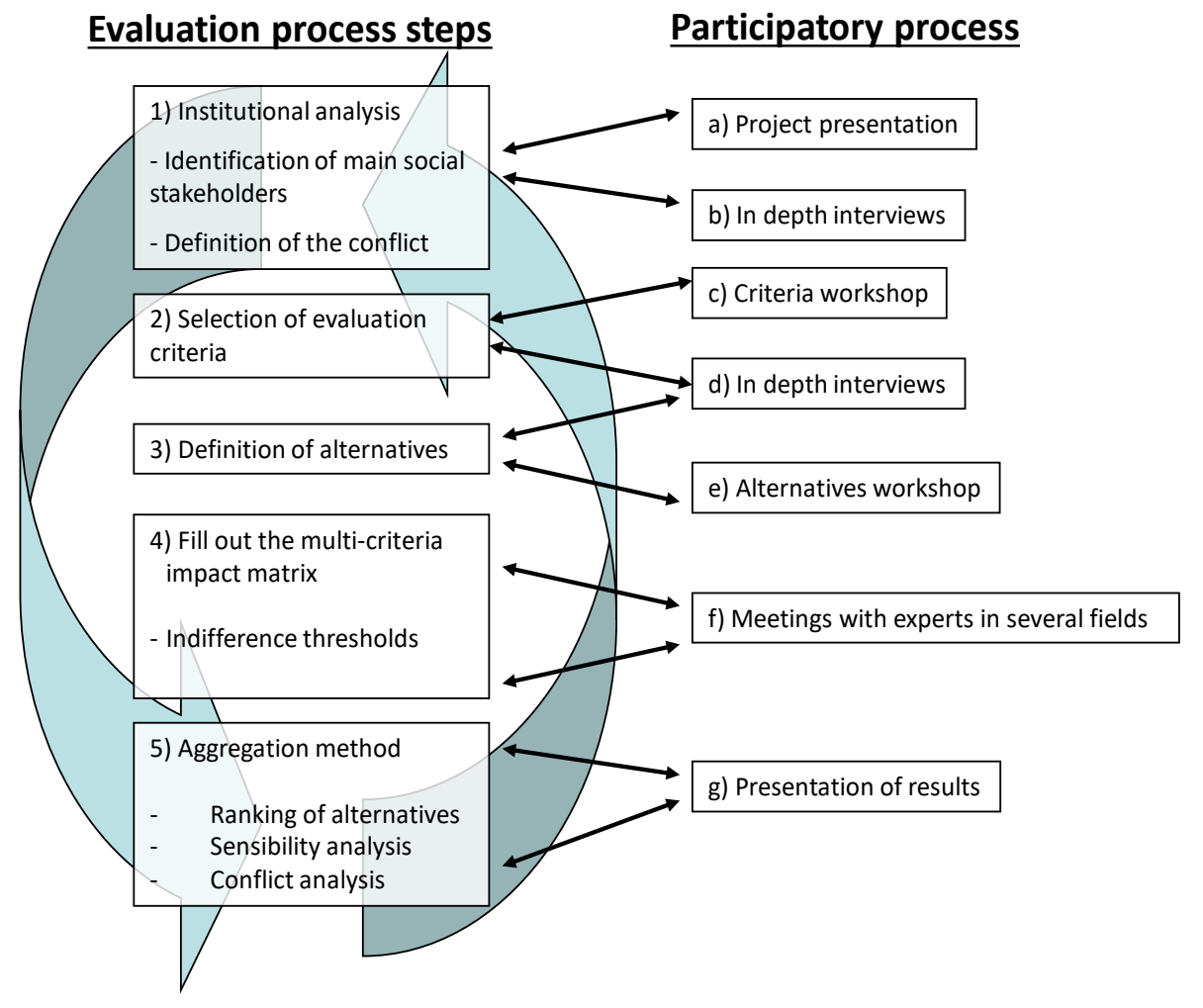

Figure 1. Evaluation process phases.

\subsection{Study Site}

Mutriku is a coastal municipality located west of Gipuzkoa (Basque Country), in the Debabarrena Valley (Figure 2), an area of approximately 2700 ha with a population of 5325 (census 2016). Due to its particular location, with a very mountainous relief and narrow valleys, and not being on the main axis of communications, there was no significant industrial development in this municipality unlike other municipalities in the area. From the ecological point of view, Mutriku also stands out for the massifs of Izarraitz, Andutz, and Arno, this last one being a Special Area of Conservation (SAC) belonging to the Natura 2000 network due to the outstanding ecological value of the Atlantic holm oak. 


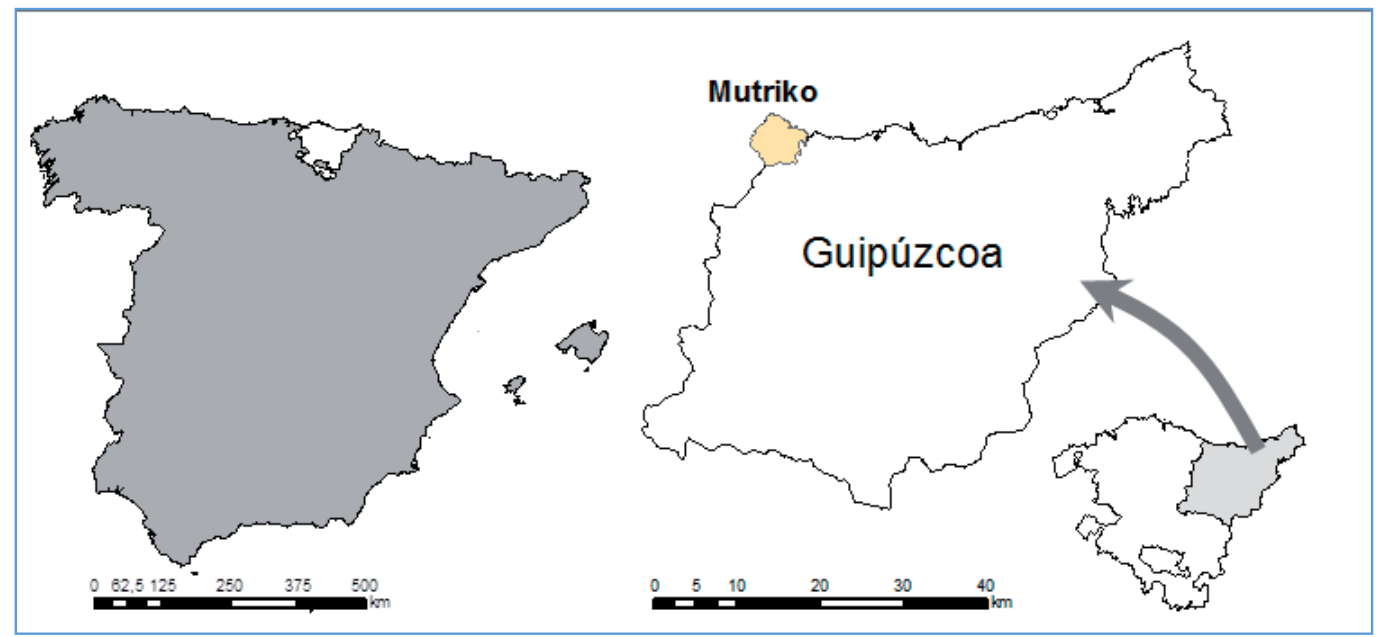

Figure 2. Map of Mutriku within Spain.

Until the mid-twentieth century, the rural areas of Mutriku maintained important agricultural activity. However, like the entire Cantabrian coast, the industrialization of the area has favored the abandonment of agricultural activity in recent decades. Thus, farmland has been reduced significantly since then in favor of forests, especially those of allochthonous species, nowadays taking up more than three-quarters of the rural land of the municipality (Table 1).

Table 1. Cultivated land and woodland in Mutriku (in ha), 1954-2012.

\begin{tabular}{ccc}
\hline & $\mathbf{1 9 5 4}$ & $\mathbf{2 0 1 2}$ \\
\hline Farmland (vegetables) & 492.01 & 55.91 \\
Meadows & 375.82 & 468.60 \\
Pasture and scrubland & 643.00 & 191.75 \\
Forestry plantations & 484.90 & 1176.60 \\
Mixed Atlantic woodland & 185.63 & 290.26 \\
Holm oak woodland & 438.07 & 459.64 \\
Urban land and Other & 101.04 & 77.71 \\
Total & 2720.47 & 2720.47 \\
\hline
\end{tabular}

Source: Author's own compilation from Subsidiary Rules of 2006 [59] and own measurements.

Most of the current farms are owned by farmers who work in a mixed way in agriculture and in industry or other work activities. In the last Agrarian Census (2009) [60], there was a decrease in the number of farms as well as in the annual work units (Table 2), predominantly small farms aimed at self-consumption and small-scale sales (beef and sheep farms basically). The constant decrease in the number of applications for compensatory grants for mountain farming ( 23 applications in 2007 and 15 in 2013) indicates that this trend has continued in recent years, so there does not appear to be a "back-to-the land" movement due to the economic downturn during the last decade [61].

Table 2. Number of agricultural holdings, Annual Work Units (AWUs), and age of holders of holdings in Mutriku, 1989-2009.

\begin{tabular}{lccc}
\hline & $\mathbf{1 9 8 9}$ & $\mathbf{1 9 9 9}$ & $\mathbf{2 0 0 9}$ \\
\hline Number of agricultural holdings & 121 & 116 & 95 \\
Agrarian Annual Work Units (AWU) & 137.3 & 134.5 & 106.5 \\
Holdings with owners under 40 years & 25 & 6 & 1 \\
Holdings with owners between 40 years and 64 years & 78 & 81 & 63 \\
Holdings with owners over 65 years & 18 & 29 & 31 \\
\hline
\end{tabular}

Source: Agrarian Census of years 1989, 1999, and 2009 [60]. 
The links of Mutriku with nearby urban labor markets have made it possible to enjoy off-farm employment chances, not very affected by the last crisis. In this sense, as happened in other regions, pluriactivity has allowed for the survival of live holdings that maintain at least a minimum agrarian activity [62-65]. However, the rate of aging of farmers is striking, leaving only one farmer less than 40 years old (Table 2). This decline in agricultural activity has also meant an important change in the landscape, where the traditional hamlet (linked to farming activities) has all but disappeared and with it a whole culture and way of life.

The SMCE carried out has been framed in the process of the elaboration of the MLUP of the municipality. The main objective was the evaluation of different alternatives of rural land uses, thus offering a useful and applicable tool to the municipal government when making decisions about it. During the institutional analysis (first phase of the SMCE), by means of the bibliographic documentary review and the first interviews with stakeholders following a bottom-up approach, four outstanding elements were identified that helped to delimit the problem around the rural planning of Mutriku:

a. Abandonment of agricultural activity. In recent decades, agricultural and livestock activity has been reduced significantly, with a high rate of aging among farmers. Much of the land previously destined to pastures and vegetables is today forests of non-native species. These factors have a significant impact on the landscape.

b. Agricultural model dependent on aid. Agro-livestock activity is no longer the main source of income on most farms. Agriculture and livestock are complementary income and their existence depends largely on public aid.

c. With the abandonment of agrarian activity, coniferous forests (non-native species), of greater economic profitability than other species, have increased significantly in recent decades. The fact that the ownership of the land is practically completely private has favored this transformation, which in any event has an important impact on the biodiversity and landscape of the area.

d. Shortage and difficulty of access to land. The orography of the Cantabrian coast, with large slopes and narrow valleys, does not offer sizeable areas for agriculture. In addition, there is a high urban pressure on these lands. On the other hand, a culture in which the land has passed from parents to children, staying for generations in the family, hinders access to land for new entrepreneurs. The model of public aid, which benefits the ownership of farms, is another factor that hinders access to land.

\section{Participatory Process}

The conditions that are established for the participatory process will determine its quality and legitimacy [31]. There are basic issues to consider in the approach to participatory processes such as the degree or intensity of participation [66], the selection of the participating stakeholders and the mode or method of participation used [67]. It is important to include all the relevant stakeholders from the point of view of the quality of the information and the efficiency of the agreements, considering that all opinions and interests have the right to participate $[68,69]$. Thus, it is necessary that the participatory processes have a wide range of participants from different areas [70,71], also combining local and scientific knowledge [72-74], which will ultimately result in the legitimacy, acceptance and transparency of the process itself [75-77], and in the social learning derived from it [31,78,79].

\subsection{Identification of the Stakeholders}

The identification of stakeholders is, therefore, a crucial aspect in the initial development of the participatory process. This task is aimed at knowing who the stakeholders related to the area of study are and what their positions and interests are, as well as the resources and tools available to defend those interests. This task begins with institutional analysis and as the process goes on, new involved stakeholders become known through the so-called snow sampling method [69]. Stakeholder selection has been undertaken, taking into account that all the views confronted have to be 
represented in the participatory process, assuring that such stakeholders have the ability and good will to participate during the whole process. According to the classification followed by other authors [35], the stakeholders involved or related to the rural area analyzed have been divided into four main groups:

a. Institutional stakeholders. Since national and European institutions have no legal power on the problem at hand, regional and local institutions are the only ones involved, i.e., the Gipuzkoa Provincial Council (GPC) and the City Council of Mutriku. Their general objective is the sustainable development of the rural environment, keeping the countryside alive and creating jobs while conserving nature. In order to reach these objectives, however, they use different models of development. This difference has been notable in forestry policies, causing several clashes in the past within the GPC. There are therefore more traditional positions and positions with greater ecological concern among the institutional stakeholders. They have regulatory and financial resources.

b. Technical stakeholders. Organizations dedicated to rural development (Debemen, HAZI, OCA, Geoparke) and agricultural unions (EHNE, ENBA). With the general objective of defining and implementing rural development policies, these agencies are dedicated to developing and implementing regional rural development programs, advise rural entrepreneurs, manage public aid and defend the rights of farmers and rural inhabitants, among other tasks. They have financial and human resources, and a broad knowledge of the rural environment and its inhabitants.

c. Economic stakeholders. Owners of the land and populating the rural area. Most of these stakeholders, traditional farmers, stand up for forestry policies in favor of the exploitation of coniferous forests because of the profitability they have generated in recent decades. Another sector of stakeholders in this group, however, formed by innovative farmers, advocates new agrarian models aimed at new markets, such as in this case ecological exploitation or farming dedicated to producing quality agricultural products. This second group demands new markets, with shorter and more direct distribution channels.

d. Social groups stakeholders. The groups of citizens that consider the rural space as a natural asset to be conserved and a place for leisure and enjoyment of free time. They prioritize ecological aspects in rural development planning. They show favorable opinions towards the protection of native species in forest policies.

Throughout the evaluation process, 32 interviews were conducted in total, with some of the technical stakeholders being interviewed more than once (Table 3). According to the procedure followed, all the interviews were developed with a previously prepared script (semi-structured), and in a place and at a time agreed with the interviewee. In addition, for valuating criteria and defining alternatives, four external experts were interviewed, i.e., two university lecturers and two rural development and agricultural technicians.

Table 3. Stakeholders interviewed.

\begin{tabular}{|c|c|c|c|}
\hline Group of Stakeholders & Stakeholders & Interviews Undertaken & Stakeholders Interviewed \\
\hline \multirow{3}{*}{ Institutional } & GPC-Ecological positions & 3 & 3 \\
\hline & GPC-Traditional positions & 2 & 2 \\
\hline & City Council of Mutriku & 5 & 5 \\
\hline \multirow{3}{*}{ Technical } & Debemen, HAZI, OCA, Geoparke & 11 & 8 \\
\hline & EHNE Union & 1 & 1 \\
\hline & ENBA Union & 1 & 1 \\
\hline \multirow{2}{*}{ Economic } & Traditional farmers & 3 & 3 \\
\hline & Innovative farmers & 2 & 2 \\
\hline \multirow{2}{*}{ Social groups } & Ecologist groups & 2 & 2 \\
\hline & Leisure groups & 2 & 2 \\
\hline
\end{tabular}

Source: Author's own compilation. 


\subsection{Process: Defining Criteria and Building Alternatives}

The exchange of information with the identified stakeholders has occurred throughout the process and through different participatory techniques (Table 4). Their contributions have been a fundamental input in the SMCE process, both in the choice of criteria and in the elaboration of alternatives.

Table 4. Milestones in the participation process.

\begin{tabular}{llll}
\hline $\begin{array}{c}\text { Phase of the } \\
\text { Evaluation Process }\end{array}$ & $\begin{array}{c}\text { Milestones in the } \\
\text { Participation Process }\end{array}$ & \multicolumn{1}{c}{ Brief Description } & Date \\
\hline $\begin{array}{l}\text { Phase 1. Institutional } \\
\text { analysis. }\end{array}$ & $\begin{array}{l}\text { Presentation of the } \\
\text { project to the City } \\
\text { Council of Mutriku }\end{array}$ & $\begin{array}{l}\text { Presentation of the project as a valid tool for } \\
\text { the preparation of the MLUP. Description of } \\
\text { the work methodology and } \\
\text { general objectives. }\end{array}$ & 16 January 2014 \\
\hline $\begin{array}{l}\text { Throughout the } \\
\text { process (the majority } \\
\text { between phases }\end{array}$ & $\begin{array}{l}\text { In-depth interviews with } \\
\text { stakeholders and experts }\end{array}$ & $\begin{array}{l}\text { Summary of opinions and positions of the } \\
\text { stakeholders, aspects that they consider } \\
\text { important in the planning of rural land and } \\
\text { positioning before different development } \\
\text { alternatives. }\end{array}$ & February 2015 \\
\hline $\begin{array}{l}\text { Phase 2. Selection of } \\
\text { evaluation criteria. }\end{array}$ & $\begin{array}{l}\text { First focus group: criteria } \\
\text { workshop }\end{array}$ & $\begin{array}{l}\text { Workshop to select the evaluation criteria. } \\
\text { Criteria that are significant for rural } \\
\text { planning are selected in a working group } \\
\text { consisting of analysts and stakeholders. }\end{array}$ & 30 June 2014 \\
\hline $\begin{array}{l}\text { Phase 3. Definition of } \\
\text { alternatives. }\end{array}$ & $\begin{array}{l}\text { Second focus group: } \\
\text { alternatives workshop }\end{array}$ & $\begin{array}{l}\text { Contrast the criteria selected in the } \\
\text { previous workshop, and define the } \\
\text { different planning alternatives through } \\
\text { rural development models. }\end{array}$ & 15 January 2015 \\
\hline $\begin{array}{l}\text { Presentation of } \\
\text { the results. }\end{array}$ & $\begin{array}{l}\text { Third workshop: } \\
\text { Presentation of results }\end{array}$ & $\begin{array}{l}\text { Present the results obtained in the technical } \\
\text { analysis to the stakeholders, and compare } \\
\text { these results with their opinions. }\end{array}$ & 19 July 2016 \\
\hline
\end{tabular}

Source: Author's own compilation.

Decisions on planning and natural resources entail a high degree of uncertainty, and the different interests and scales that converge in these decisions require in-depth and elaborate information. Thus, qualitative participatory methods are appropriate because they permit in-depth knowledge of both the problems and the positions of the stakeholders, and offer sufficient time for both stakeholders and analysts to deliberate and participate in the social learning process $[66,80,81]$ as well as to reach consensus $[31,69]$. The participatory techniques used in this evaluation process have basically been semi-structured in-depth interviews and focus groups, in accordance with the objectives sought and in line with the experiences of other works [82]. These are regular techniques in combination with the snow sampling method during the first step of stakeholder analysis [69].

In order to define and decide the evaluation criteria and possible planning alternatives for rural land, two focus groups were carried out, according to the pertinence of the technique for this [83] and a third was used to present the results. In the first one, the criteria that are considered important for the future of rural land were chosen, that is the criteria according to which the development alternatives will be evaluated later. In agreement with previous works, the chronological order of the workshops employed was to avoid strategic behaviors by the stakeholders in favor of their interests $[78,84]$.

For the first focus group, 25 stakeholders were invited and 19 of them attended, but all stakeholder groups were represented. The objective of the session was to elicit the required information for shaping evaluation criteria. After a brief introduction, the discussion was structured around three main questions: (1) Which are the most important issues in the rural area of Mutriku?; (2) What do you value most in that area?; (3) How do you envisage its future?. Then, stakeholders were divided into two groups, where all the interests were represented. Stakeholders expressed their needs and expectations orally and in writing, which was collected by the evaluators. In each group, one evaluator moderated 
the discussion to ensure equitable participation and avoid dominant behaviors. The session finished with an open debate among all stakeholders.

Once the criteria were chosen and defined, in a second focus group the possible alternatives or models of rural planning were raised. This focus group aimed to validate the criteria defined previously, and elicit information to build evaluation alternatives. Twenty stakeholders attended the meeting and the representativeness of the interests in dispute was assured. During the session, first, the participants agreed on a set of evaluation criteria according to economic, environmental and social dimensions. Second, following the structure of the previous workshop, stakeholders were divided into two groups moderated by an evaluator, which allows participants to present their positions and ensures a balance among contrasting views. Evaluators presented five different alternatives of rural development for Mutriku, which were discussed in each group. Finally, an open discussion was held among all participants. Overall, the alternatives proposed were rejected by stakeholders and guidelines for their re-definition were collected by evaluators.

After the debate with the stakeholders, this workshop showed the need to rethink the alternatives initially proposed by the group of evaluators, defining new development alternatives more suited to the particularities and specific situation of the area. It is thus necessary to point out the determining factor, i.e., the participation of the stakeholders through this second focus group, with this being a decisive meeting for the construction of the alternatives.

In the third meeting, the technical results obtained in the evaluation process were presented and discussed. As only nine stakeholders attended the workshop, an open discussion was undertaken after the main results had been expounded by evaluators. However, a technical report was delivered either by mail or email to all participants in the process, and feedback was received from them. The results had different levels of acceptance by the stakeholders, revealing the underlying conflict of the different models of rural development evaluated.

\subsubsection{Definition of Criteria}

The evaluation criteria are the technical expression of the interests, expectations, and desires of the stakeholders, and must represent the multiple dimensions of the problem [44,45]. The criteria are the tool through which alternatives are compared from different points of view. To evaluate the different alternatives, therefore, it is necessary to select a series of criteria that represent the relevant aspects and the interests of the stakeholders. Table 5 shows the selected criteria, the interests they reflect, and the method of evaluating them.

Table 5. Definition of evaluation criteria.

\begin{tabular}{|c|c|c|c|}
\hline Dimension & Criteria & Needs and Expectations & Indicator/Evaluation Scale \\
\hline \multirow{2}{*}{ 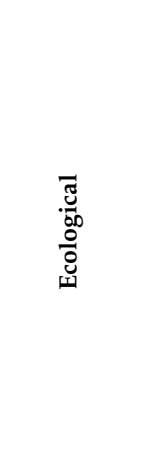 } & 1. Biodiversity & $\begin{array}{l}\text { - Conserve the diversity of the flora and fauna of the } \\
\text { rural area. } \\
\text { - Develop forestry management that allows the conservation } \\
\text { of biodiversity. } \\
\text { - Promote agricultural practices that are respectful } \\
\text { of biodiversity. } \\
\text { - Protect local species (seeds, autochthonous species, etc.). }\end{array}$ & $\begin{array}{l}\text { Zoogeographic assessment. } \\
\text { Unit: index } \\
\text { Direction: maximize }\end{array}$ \\
\hline & 2. Landscape & $\begin{array}{l}\text { - The landscape as an indicator of conservation of the } \\
\text { natural environment. } \\
\text { - } \quad \text { Value the landscape formed by traditional agriculture. } \\
\text { - } \quad \text { Analyze the impact of forestry models on the landscape. }\end{array}$ & $\begin{array}{l}\text { Phytogeographic } \\
\text { assessment. } \\
\text { Unit: index } \\
\text { Direction: maximize }\end{array}$ \\
\hline
\end{tabular}


Table 5. Cont.

\begin{tabular}{|c|c|c|c|}
\hline Dimension & Criteria & Needs and Expectations & Indicator/Evaluation Scale \\
\hline \multirow{2}{*}{ 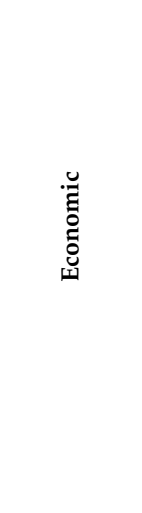 } & $\begin{array}{l}\text { 3. Income from } \\
\text { agricultural activities }\end{array}$ & $\begin{array}{l}\text { - Creation of employment in the first sector. Attraction } \\
\text { of young people. } \\
\text { - } \quad \text { Avoid excessive dependence on CAP aid. } \\
\text { - Stop the abandonment of agricultural holdings and } \\
\text { facilitate the acquisition of land for new entrepreneurs. } \\
\text { - } \quad \text { Develop profitable agricultural and forestry models } \\
\text { and research new markets for agricultural products. }\end{array}$ & $\begin{array}{l}\text { Net margin obtained in } \\
\text { agricultural and } \\
\text { forestry holdings. } \\
\text { Unit: euros } \\
\text { Direction: maximize }\end{array}$ \\
\hline & 4. Public cost & $\begin{array}{l}\text { - Aid to the agricultural sector is an important part of } \\
\text { their income but a social cost at the same time. } \\
\text { - Public aid must promote sustainable agrarian models, } \\
\text { instead of perpetuating the current model in crisis. } \\
\text { - The cost of infrastructure in rural areas is burdensome } \\
\text { for administrations, especially for } \\
\text { local administrations. }\end{array}$ & $\begin{array}{l}\text { Subsidies received by farms } \\
\text { and forestry. } \\
\text { Unit: euros } \\
\text { Direction: minimize }\end{array}$ \\
\hline \multirow[t]{2}{*}{.ֶّ } & $\begin{array}{l}\text { 5. Consumption of } \\
\text { local products }\end{array}$ & $\begin{array}{l}\text { - Commitment, sensitization, and awareness of } \\
\text { producers and consumers. } \\
\text { - Need to increase local demand for products. Decrease } \\
\text { external dependence. Promote short } \\
\text { distribution channels. } \\
\text { - } \quad \text { Importance of agricultural activities being profitable to } \\
\text { ensure their viability. } \\
\text { - The administration should promote research into new } \\
\text { modes of production and marketing of agricultural } \\
\text { products, as well as actions of social awareness. }\end{array}$ & $\begin{array}{l}\text { Proportion of local products } \\
\text { consumed by the population. } \\
\text { Unit: qualitative assessment } \\
\text { Direction: maximize }\end{array}$ \\
\hline & $\begin{array}{l}\text { 6. Attachment to the } \\
\text { rural land }\end{array}$ & $\begin{array}{l}\text { - Maintain and transmit rural culture and knowledge. } \\
\text { Value the contribution of the work of farmers and } \\
\text { ranchers for the maintenance of the landscape and the } \\
\text { - Guarantee the quality of life in rural areas: services } \\
\text { and infrastructure. }\end{array}$ & $\begin{array}{l}\text { Maintenance and } \\
\text { conservation of a live } \\
\text { rural environment. } \\
\text { Unit: qualitative assessment } \\
\text { Direction: maximize }\end{array}$ \\
\hline
\end{tabular}

Source: Author's own compilation.

It should be noted that, in this process, the participation of stakeholders has been decisive since the criteria have been defined in the first instance based on (a) the information from the in-depth interviews and (b) the content of the first focus group, whose results were contrasted in the second. Subsequent technical work has been helped by external experts and evaluators. As a result of the entire process, six criteria were selected according to the paradigm of agricultural multifunctionality: landscape and biodiversity reflect the ecological dimension; agricultural incomes and the public cost of the measures reflect the economic dimension; and the consumption of local products and attachment to the land represent the social dimension.

\subsubsection{Construction of the Alternatives}

The institutional analysis and the participatory process, as a whole, have shown the different visions and positions held by the stakeholders on the rural development model and the consequent spatial planning for the non-urban land of Mutriku. Thus, there are three main planning scenarios linked respectively to three other models of rural development: (1) maintain the current dynamics (business as usual-BAU); (2) promote new sustainable agricultural and livestock models; and (3) promote a forestry model based on native species. These three scenarios, in turn, are specified in five alternatives. It has already been pointed out that, for this selection, the second focus group was decisive. In this group, technical work was carried out jointly with external experts in order to adequately build alternatives whilst respecting the viability of the activities in each one. Thus, each of the alternatives proposes a plausible development model with different rural land uses. These alternatives have been 
mapped using GIS (Figures 3-6), so that in addition to the evaluation, it is possible to see the impact of the different land uses in each of them. Table 6 shows the main characteristics of each alternative and Table 7 summarizes the differentiating elements of each alternative with respect to the current situation.

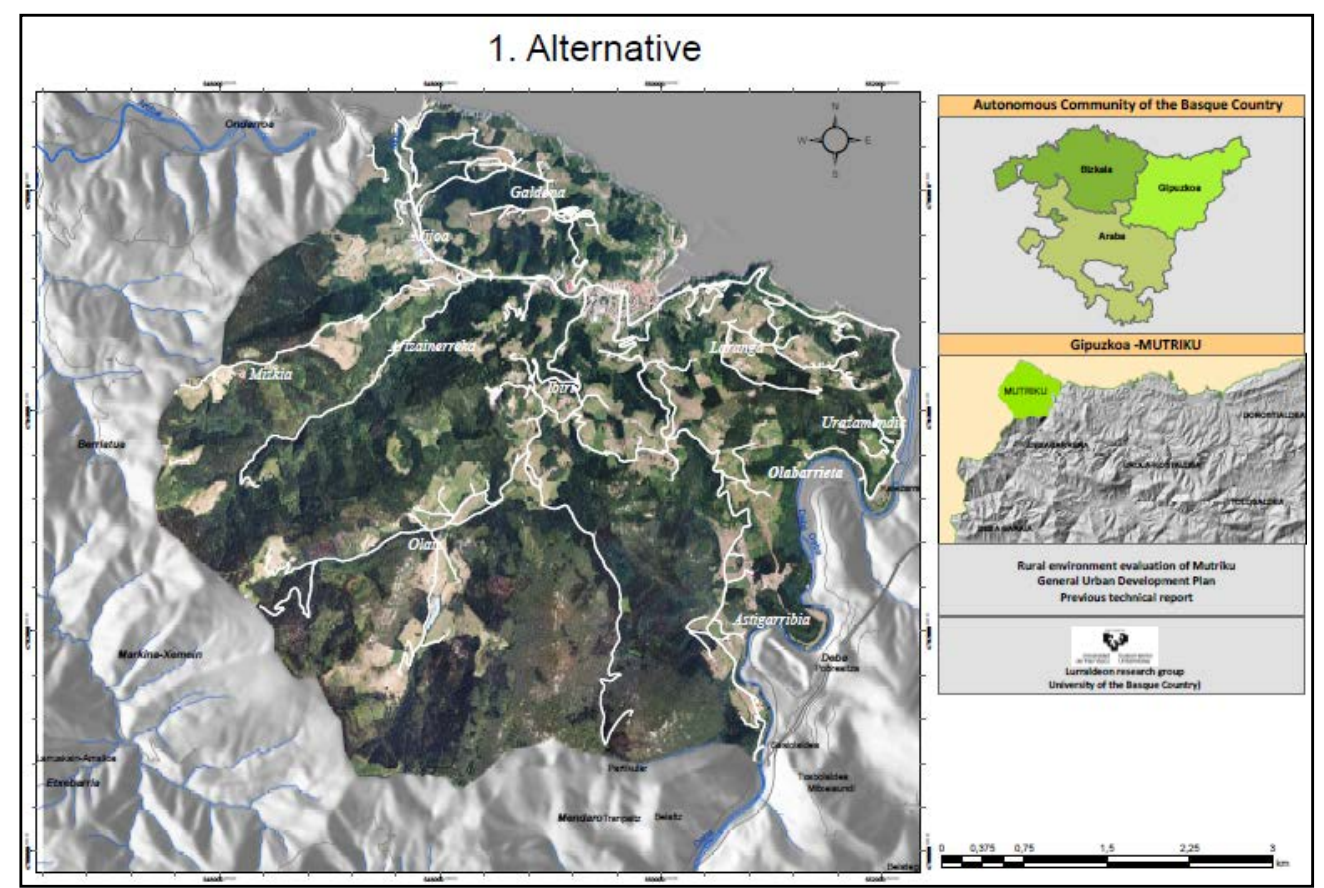

Figure 3. Aerial photo of Alternative 1.

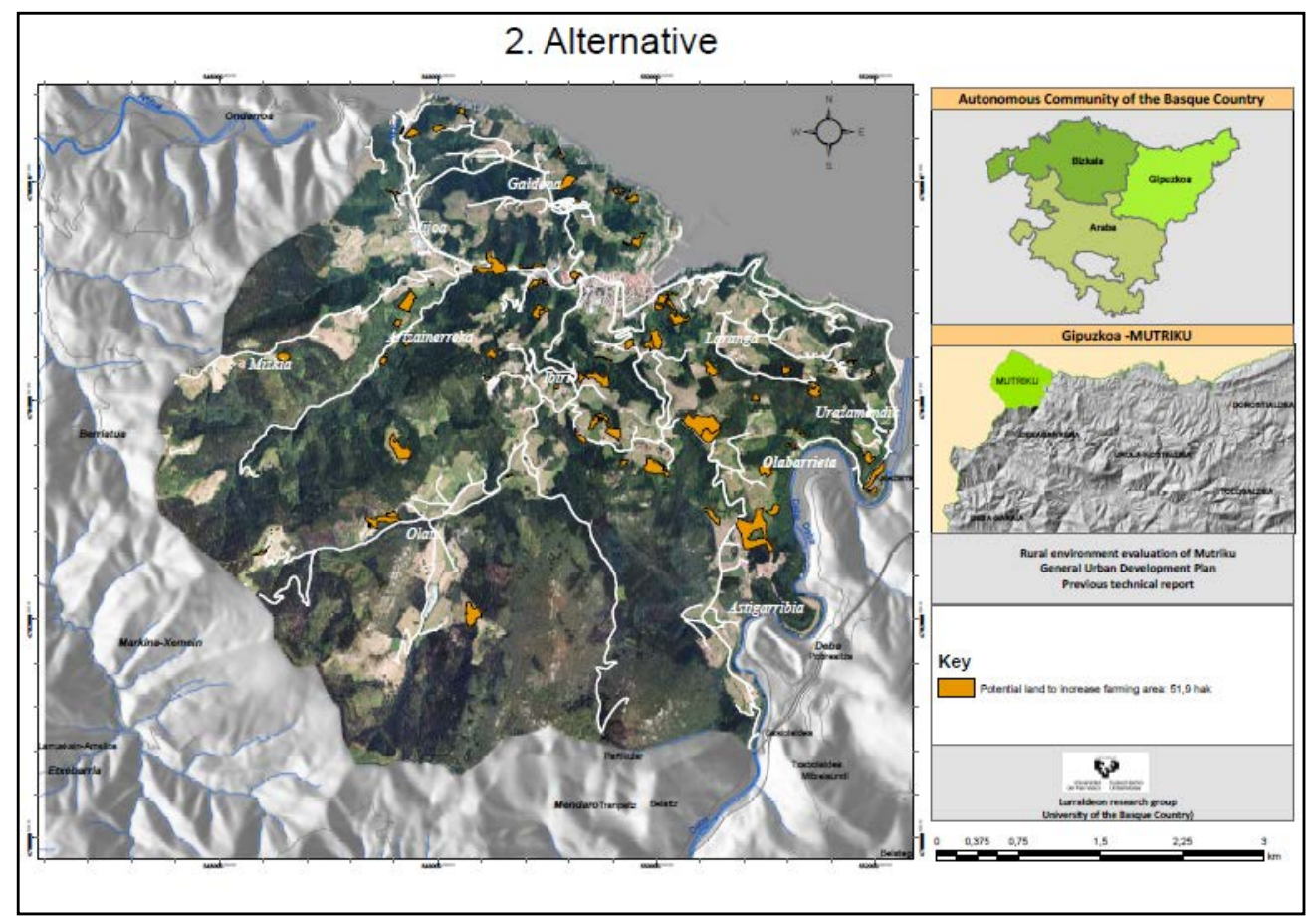

Figure 4. Aerial photo of Alternative 2. 


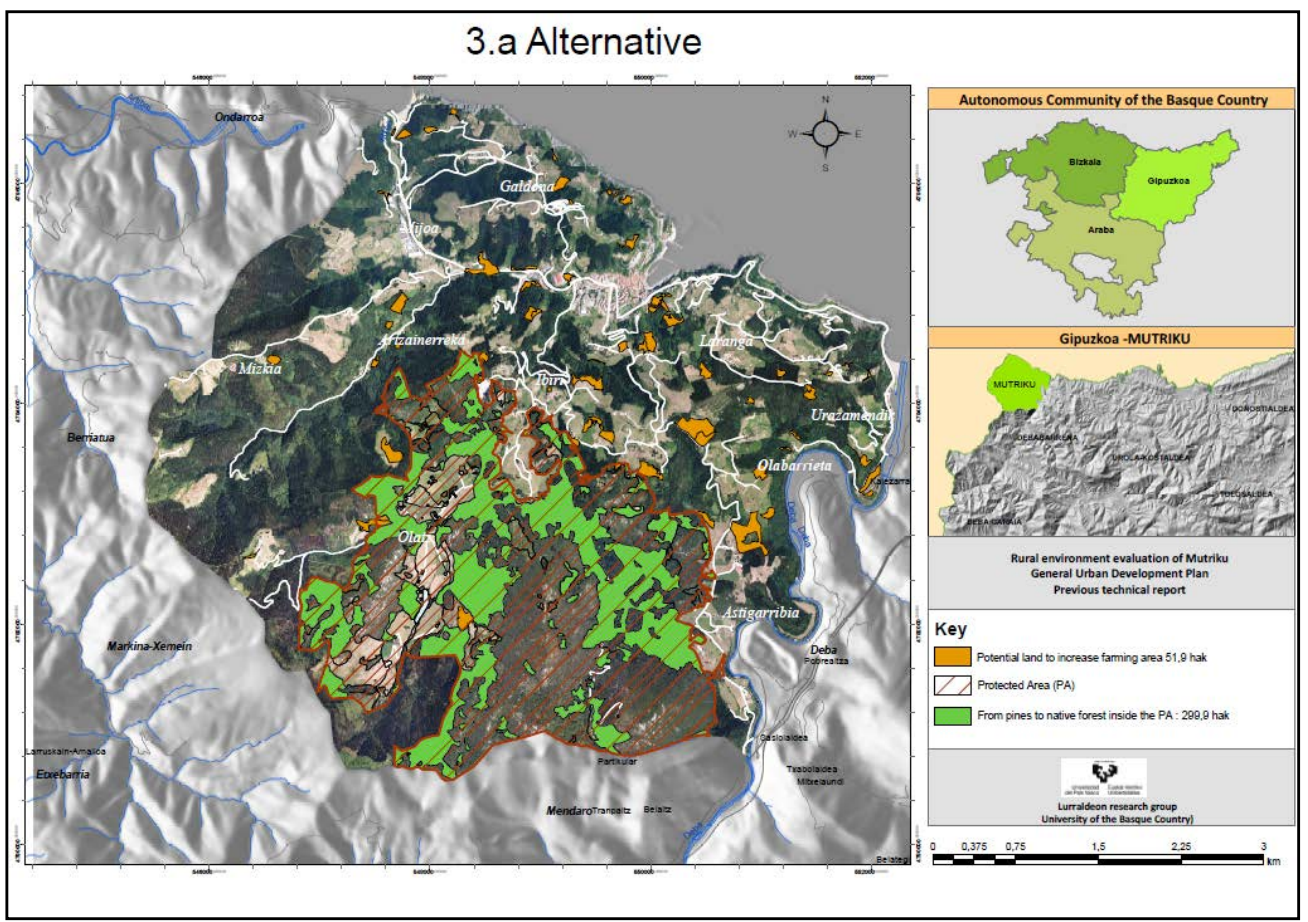

Figure 5. Aerial photo of Alternative 3a.

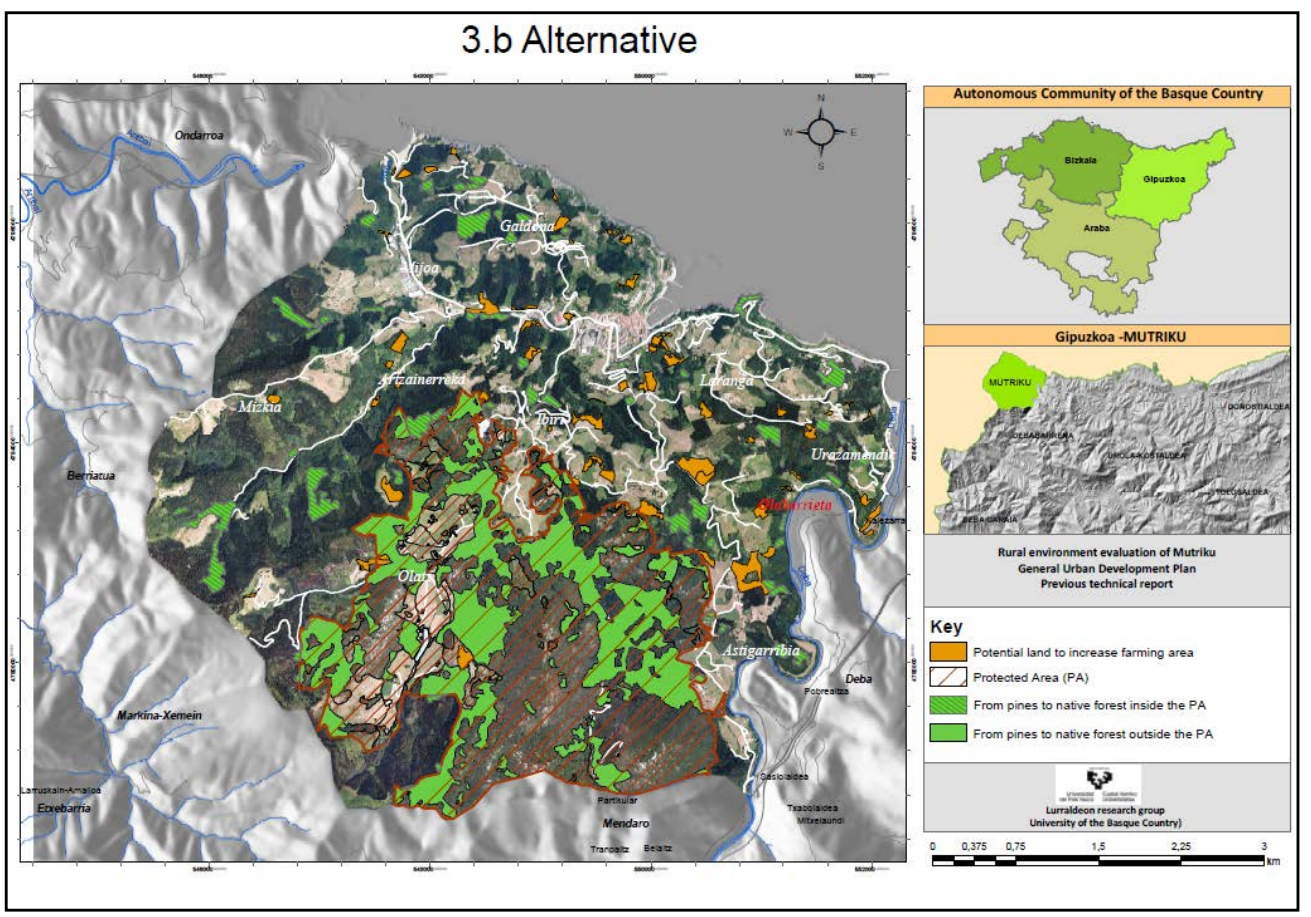

Figure 6. Aerial photo of Alternative 3b.

Table 6. Description of each alternative.

\section{Alternative 1: Maintain the current dynamics (Business as usual-BAU)}

This alternative reflects the future scenario in the case of maintaining the general dynamics of the last three or four decades. A gradual reduction of the agricultural activity and the maintenance or proliferation of coniferous forests is foreseen. No changes are anticipated in land use, legislation, or municipal planning. 
Table 6. Cont.

\section{Alternative 2a: Medium promotion of new agrarian models}

In this scenario, it is proposed to promote and develop agricultural holdings aimed at the production of ecological and quality products, which are profitable without relying on subsidies. This alternative involves developing and enhancing the demand for these products through awareness and favoring short distribution channels. This alternative proposes the recovery of all the lands used in the 1950s that are currently in disuse for the primary sector, amounting to some 51.9 ha that are currently classified as scrub. In particular, it is proposed to establish two farms for organic products, two greenhouses, a new holding of fruit trees, a sheep farm and another farm for beef in these areas. In relation to the wooded area, current policies and uses would be maintained.

\section{Alternative 2b: Intense promotion of new agrarian models}

This is an additional part to Alternative 2a, but to reflect a greater empowerment of new agricultural models, a larger livestock farm is proposed than in 2a on lands that are currently occupied by forestry plantations (note: the new livestock farm would occupy private lands. So as not to create conflict among the potential owners, it has not been reflected on the map).

Alternative 3a: New agrarian models and medium promotion of the autochthonous forest

In addition to the promotion of new agrarian models detailed in Alternative 2a, a change of forest policy is advocated in favor of a larger area of native species to the detriment of non-native plantations (radiata pine, eucalyptus). The conversion of the current 299.9 ha of pine in the Arno SAC to autochthonous species is proposed.

\section{Alternative 3b: New agrarian models and intense promotion of the autochthonous forest}

This alternative is also based on the promotion of new models of agriculture and livestock in Alternative 2a. For the forestry sector, however, the conversion of non-native species to autochthonous species in 377.7 ha within and outside the SAC is proposed.

Source: Author's own compilation.

Table 7. Differentiating elements of each alternative with respect to the current situation.

\begin{tabular}{|c|c|c|c|c|c|}
\hline & Alt. 1 & Alt. 2a & Alt. $2 b$ & Alt. 3a & Alt. $3 b$ \\
\hline 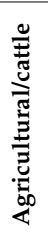 & $\begin{array}{l}\text { Continues the } \\
\text { current } \\
\text { dynamics }\end{array}$ & $\begin{array}{l}\text { + } 2 \text { ecological holdings } \\
(4 \text { ha) } \\
+2 \text { greenhouses }(1 \mathrm{ha}) \\
+1 \text { fruit orchard }(3 \mathrm{ha}) \\
+1 \text { sheep farm }(22.5 \mathrm{ha}) \\
+1 \text { beef farm }(20 \mathrm{ha}) \\
\text { - Reduction in scrubland } \\
\text { ( } 50.5 \mathrm{ha})\end{array}$ & $\begin{array}{l}\text { Alt. } 2 \mathrm{a} \\
+1 \text { sheep farm } \\
(22.5 \text { ha })\end{array}$ & Alt. 2a & Alt. 2a \\
\hline 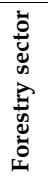 & $\begin{array}{l}\text { Continues the } \\
\text { current } \\
\text { dynamics }\end{array}$ & Current forestry use & $\begin{array}{l}\text { - Reduction in pine } \\
\text { forest ( } 22.5 \mathrm{ha})\end{array}$ & $\begin{array}{l}+\quad \text { Native forest in SAC } \\
\text { Arno (299.9 ha) } \\
-\quad \text { Pine forest in SAC } \\
\text { Arno (299.9 ha) }\end{array}$ & 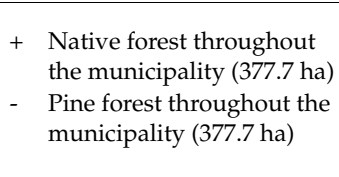 \\
\hline
\end{tabular}

Source: Author's own compilation.

\section{Evaluation: Integrating Multifunctionality and Incorporating Opposite Visions}

\subsection{Valuation of Criteria}

As has been pointed out, the SMCE allows for us to overcome technical incommensurability by incorporating valuations of different dimensions without the need for all of them to be reduced to a single measure. Thus, the six selected criteria have been assessed through different methodologies and using different units of measurement. In some cases, the qualitative assessment is more appropriate, given that by its very nature some criteria may be difficult to quantitatively assess, or there may even be no reliable data or sources for a correct quantification of the impacts. Thus, the evaluation of the criteria has involved an important technical work in which experts from different scientific fields have collaborated.

The steps taken in this assessment process are the following: (1) choice of indicators that best represent the evaluation criteria to assess the impacts of each alternative; (2) collection of information and data sources necessary for the evaluation; (3) choice of spatial and temporal scales in which 
indicators are valued; (4) evaluation of the alternatives, which have finally been integrated into the MCIM. The assessment of each criterion is briefly described below.

\subsubsection{Biodiversity}

To assess the biodiversity criterion, a specific index based on an ad hoc zoogeographic assessment was implemented for the area under study [85]. To make up this index, qualitative and quantitative inventories were carried out on the fauna of each of the seven local habitats identified in Mutriku. The empirical and methodological consistency of such index was tested for the same region in previous fieldworks [86,87]. Moreover, the specifically relevant information gathered on-site made this choice the best available.

Different methods and specific tools were applied for measurement and evaluation such as local eye measurements, listening stations, interviews with local agents, and consultation of documentation related to the environment. First, the area to be studied was zoned into environmental units or habitats that correspond to each land use. As can be seen in Table 8, the rural land of Mutriku consists of seven different land uses. For the quantitative analysis, the number of taxa of each species is quantified, and as for the qualitative analysis, the protected species and their degree of risk as well as plague species and their effect are valued. For the zoogeographic valuation $(\mathrm{ZV})$, the following variables and their relation are considered according to the following formula: number of species $(\mathrm{N})$, protected species (PE), vulnerable species (VU), rare species (RA), species of special interest (SI) and introduced species (INT).

$$
\mathrm{ZV}=\mathrm{N}+\{5 \times(\mathrm{PE})+4 \times(\mathrm{VU})+3 \times(\mathrm{RA})+2(\mathrm{SI})\}-\mathrm{INT}
$$

Thus, the environmental units identified in the rural land of Mutriku obtain a certain zoogeographic valuation. The score corresponding to each of the alternatives is calculated based on the different land uses raised in them. Starting from works that relate biodiversity and the extension of the different land uses [88], it is deduced that although this relation is not directly proportional, in smaller dimensions the smallest variations have a direct effect. Therefore, to calculate the biodiversity valuation for each proposed alternative, the ha of each environmental unit has been multiplied by the zoogeographic valuation of said unit (Table 8).

Table 8. Valuation of biodiversity for each alternative.

\begin{tabular}{ccccccc}
\hline & \multicolumn{5}{c}{ Zoogeographic Valuation } \\
\hline Land Use & ZV & Alt. 1 & Alt. 2a & Alt. 2b & Alt. 3a & Alt. 3b \\
\hline Mixed Atlantic woods & 127 & 35,907 & 35,907 & 35,907 & 73,994 & 83,875 \\
Holm oak woodland & 128 & 58,834 & 58,834 & 58,834 & 58,834 & 58,834 \\
Riverside vegetation & 113 & 851 & 851 & 851 & 851 & 851 \\
Coniferous woodland & 56 & 65,890 & 65,890 & 64,770 & 49,095 & 44,738 \\
Pasture and scrubland & 119 & 17,833 & 13,006 & 13,006 & 13,006 & 13,006 \\
Farmland & 93 & 62,417 & 68,593 & 70,973 & 68,593 & 68,593 \\
Urban land & 47 & 3652 & 3652 & 3652 & 3652 & 3652 \\
& & 245,383 & 246,732 & 247,992 & 268,025 & 273,549 \\
\hline
\end{tabular}

Source: Author's own compilation.

\subsubsection{Landscape}

The valuation of the landscape is also done through an index calculated ad hoc for this piece of research. As was the case for the biodiversity criterion, environmental sound information gathered on-site makes it possible to shape an ad hoc index. For this purpose, diverse methodological approaches of LANBIOEVA (Landscape Biogeographic Evaluation) were used [89-91], being adapted to this case study [92]. This methodology offers a resulting index called PRICON, which has already been used for valuing the landscape within SMCE [53]. Furthermore, the fact that $28 \%$ of Mutriku's surface is under Natura 2000 [93] makes appropriate the use of PRICON for valuing the overall 
landscape. In fact, this index includes a phytogeographic valuation that includes the natural, cultural, and conservation interest of each environmental unit or land use identified. The PRICON index is based on two sub-indices: the general natural interest index (INNAT), based on the valuation of environmental aspects, and the cultural interest index (INCUL) based on ethnobotanical, didactic, and perception values.

The INNAT sub-index, in turn, is calculated considering the general phytogenic interest (INFIT), the general territorial interest (INTER), and the general mesological interest (INMES). The INNAT sub-index takes values between 8 and 160, according to the following formula:

$$
\text { INNAT }=\text { INFIT (from } 1 \text { to 50) }+ \text { INTER (from } 1 \text { to 50) + INMES (from } 6 \text { to } 60)
$$

The INCUL sub-index, on the other hand, collects cultural values, whose consideration is increasingly important for environmental awareness and conservation policies. Ethnobotanical values (ETNO), perception values (PER), and didactic values (DID) are considered for the calculation of this sub-index. This sub-index acquires values between 4 points and 40 points, and is calculated through the following formula:

$$
\mathrm{INCUL}=\mathrm{ETNO}(\text { from } 2 \text { to } 20)+\text { PER (from } 1 \text { to } 10)+ \text { DID (from } 1 \text { to } 10)
$$

Considering these sub-indices and the conservation interest level of the land under study, the PRICON index score is calculated for each environmental unit. For this valuation, 54 inventories were made that allowed the calculation of said sub-indices for each of the environmental units studied and also the calculation of the PRICON index for each one of them [92]. From this index, the landscape valuation has been made by calculating its value according to the surfaces of the environmental units in the different alternatives evaluated (Table 9).

Table 9. Valuation of landscape for each alternative.

\begin{tabular}{ccccccc}
\hline & & \multicolumn{5}{c}{ Landscape Valuation } \\
\hline Land Use & PRICON & Alt. 1 & Alt. 2a & Alt. 2b & Alt. 3a & Alt. 3b \\
\hline Mixed Atlantic woods & $\mathbf{2 1 5 2 . 5 0}$ & 608,576 & 608,576 & 608,576 & $1,254,111$ & $1,421,575$ \\
Holm oak woodland & $\mathbf{1 9 3 5 . 9 0}$ & 889,817 & 889,817 & 889,817 & 889,817 & 889,817 \\
Riverside vegetation & $\mathbf{2 0 0 8 . 9 0}$ & 15,127 & 15,127 & 15,127 & 15,127 & 15,127 \\
Coniferous woodland & $\mathbf{8 7 7 . 5 0}$ & $1,032,466$ & $1,032,466$ & $1,014,916$ & 769,304 & 701,034 \\
Pasture and scrubland & $\mathbf{1 0 5 9 . 1 0}$ & 203,082 & 148,115 & 148,115 & 148,115 & 148,115 \\
Farmland & $\mathbf{1 1 5 5 . 0 0}$ & 605,809 & 665,753 & 688,853 & 665,753 & 665,753 \\
Urban land & $\mathbf{4 1 6 . 0 0}$ & 32,327 & 32,327 & 32,327 & 32,327 & 32,327 \\
& & $\mathbf{3 , 3 8 7 , 2 0 6}$ & $\mathbf{3 , 3 9 2 , 1 8 3}$ & $\mathbf{3 , 3 9 7 , 7 3 3}$ & $\mathbf{3 , 7 7 4 , 5 5 5}$ & $\mathbf{3 , 8 7 3 , 7 5 0}$ \\
\hline
\end{tabular}

Source: Author's own compilation.

\subsubsection{Agrarian Income}

This criterion includes income generated by agricultural, livestock, and forestry activities associated with each alternative, without including subsidies. This criterion is valued quantitatively, in euros. The main source of information for this assessment has been the data offered by the GPC on the annual income of farms in the rural area studied. The net margin is the indicator used to reflect the income obtained by agricultural holdings. The values have been calculated based on Order 3397 of the Basque Government [94], which collects information on gross margins, annual work units, expense ratios, and net margins of agricultural holdings.

The GPC provided data referring to the agricultural incomes obtained in the Mutriku farms in the year 2014 (the most recent year available). This data has been used to value Alternative 1, which amounts to 367,028 euros/year. Other alternatives have been calculated based on the new 
agricultural and livestock farms proposed and the new forest uses contemplated in each one of them (Table 10).

Table 10. Variation and total agrarian income obtained in each alternative, net margin (euros).

\begin{tabular}{cccccc}
\hline & Alt. 1 & Alt. 2a & Alt. 2b & Alt. 3a & Alt. 3b \\
\hline Net margin for new agricultural holdings & - & $+88,871$ & $+88,871$ & $+88,871$ & $+88,871$ \\
Net margin for new cattle farms & - & +3395 & +6455 & +3395 & +3395 \\
Net margin for change of pine forest to cattle use & - & & -1234 & & \\
Net margin for increase in native woodland & - & & & $+11,035$ & $+14,410$ \\
Net margin for reduction in pine forest & - & & & $-29,814$ & $-38,061$ \\
Variation in income & - & $+92,267$ & $+94,092$ & $+73,487$ & $+68,615$ \\
Total income & 367,028 & 459,295 & 461,120 & 440,515 & 435,643 \\
\hline
\end{tabular}

Source: Author's own compilation.

\subsubsection{Public Cost}

This criterion was valued quantitatively, in euros, and the aim is to minimize its value. The agricultural, livestock, and forestry subsidies granted by different public administrations were calculated for the agrarian farms in the region, since this aid supposes a cost for society in general. The main source of information was the database provided by the Basque Government in which the aid is collected, both from the EU and the state and those from the Basque Government and the GPC.

As in the previous case, the current subsidies of the agricultural, livestock, and forestry holdings of the municipality of Mutriku were evaluated, but to avoid exogenous biases, the average of the years 2012, 2013, and 2014 was taken (most recent data). For the calculation of aid, two sources were used: firstly, Provincial Decree 66/2008, in which aid from the EU is developed and regulated through the Rural Development Program of Euskadi and; secondly, aid co-financed by the Basque Government and regulated through the EREIN program for the creation of new jobs. On the other hand, aid to forestry operations was calculated on the basis of Foral Decree 77/2008 for the conservation, improvement, and maintenance of Gipuzkoa's forests. The aid that the forestry sector would receive in Alternatives $3 \mathrm{a}$ and $3 \mathrm{~b}$ is calculated on the basis of loss of earnings for promoting forests of native species. This aid is contemplated for protected areas in the Natura 2000 network, being the case of the forestry change proposed in Alternative 3a. However, in Alternative 3b, the concession of the same amounts in non-protected areas is considered, given that they are the most realistic for the proposal of forest management based on native species. Table 11 summarizes the aid from subsidies in the different alternatives.

Table 11. Amount of the total subsidies of the different alternatives (in euros).

\begin{tabular}{cccccc}
\hline & Alt. 1 & Alt. 2a & Alt. 2b & Alt. 3a & Alt. 3b \\
\hline Public cost & 379,429 & 416,259 & 426,565 & 561,801 & 599,444 \\
\hline \multicolumn{6}{c}{ Source: Author's own compilation. }
\end{tabular}

\subsubsection{Consumption of Local Products}

This criterion reflects the daily consumption of local products by the inhabitants of Mutriku. To assess local consumption, various sources of information have been used since there is no reliable data on such consumption, nor is it easy to make quantitative forecasts about it. The qualitative assessment is a good option when there is no reliable quantitative data and the uncertainty is high [84]. For these reasons, the consumption of local products is assessed through a qualitative scale based on the information collected in the institutional analysis and interviews with local agents, and complemented with qualitative information obtained from technicians and academics with knowledge of the subject, following the guidelines of previous research projects [51,84,95-97]. 
In fact, the difficulties of calculation are not only due to the scarcity of information about the offer of local products at the moment, but also because there is not enough knowledge of the potential demand of these products that could exist in the future, taking into account that in some of the proposed alternatives a substantial increase in the supply of these products and a greater awareness and sensitization in favor of their consumption is foreseen.

However, after analyzing the set of information collected, we have been able to draw some relevant conclusions. From the point of view of the offer, the agricultural activity in Mutriku is very scarce, and all the products that are offered locally are sold without difficulties in the region (both that which comes from traditional agriculture as well as that from greenhouse and ecological agriculture). It could be said, therefore, that in the case of agricultural products, currently the demand is greater than the supply. With regards to livestock and the forestry sector, though, their products are sold to intermediaries who redistribute them in more distant markets.

On the other hand, it is necessary to point out that although there is an expected increase in the demand for local products, this will depend largely on the impulse of public purchase (schools, nursing homes), the strengthening of local markets, and the increase in the level of awareness of the population.

Taking into account all of the above, the assessment of the current situation (Alternative 1) is quite unfavorable, while the measures proposed and the new exploitation foreseen in Alternatives $2 \mathrm{a}$ and $2 \mathrm{~b}$ suppose greater local consumption, provided that the condition that everything produced meets its corresponding local demand is fulfilled. In Alternatives $3 a$ and $3 b$, finally, it was assumed that forest plantations continue offering their products to external markets, as is currently the case. Therefore, no changes are expected in the forestry sector and its valuation is limited to the influence of the new agro-livestock farms (remember that Alternatives $3 \mathrm{a}$ and $3 \mathrm{~b}$ include the same agro-livestock features of Alternative 2a). In such a way, the qualitative assessment of alternatives was made according to a scale from 1 to 9 , as follows: 1 , completely bad; 2 , very bad; 3, bad; 4 , quite bad; 5 , average; 6 , quite good; 7, good; 8 , very good; 9 , excellent (Table 12).

Table 12. Valuation of consumption of local products.

\begin{tabular}{cccccc}
\hline & Alt. 1 & Alt. 2a & Alt. 2b & Alt. 3a & Alt. 3b \\
\hline Consumption of local products & Quite bad & Quite good & Good & Quite good & Quite good \\
\hline & Source: Author's own compilation. &
\end{tabular}

\subsubsection{Attachment to the Rural Land}

This criterion considers various cultural aspects such as the maintenance of a living rural world, the importance of the farmer in maintaining the landscape, and local knowledge. As in the previous criterion, there is no reliable quantitative information to adequately assess the attachment of each of the alternatives proposed. Therefore, we chose to assess this criterion qualitatively based on the information obtained through institutional analysis, interviews with local stakeholders, the two group dynamics, and several consultations with experts.

At the time of assessing the current situation, it was taken into account that nowadays the activity of the primary sector is low and is in sharp decline, threatening a generational change. However, local knowledge is still transmitted and society values the contribution of farmers to the maintenance of rural culture and the natural environment. Therefore, it was considered that the current level of attachment in Alternative 1 is medium. Alternatives $2 \mathrm{a}$ and $2 \mathrm{~b}$ would increase this level of attachment by attracting young people to the rural area and reactivating the activity of the sector. On the other hand, the decrease in the exploitation of conifers in Alternatives 3a and 3b would mean a reduction in agricultural incomes, a greater abandonment of farms and an obstacle to the generational change, reducing the traditional way of life and the culture of the hamlet, that is, decreasing the level of attachment. In this respect, see Table 13, which is based on the same qualitative scale used for Table 12. 
Table 13. Level of attachment to the land of the different alternatives.

\begin{tabular}{cccccc}
\hline & Alt. 1 & Alt. 2a & Alt. 2b & Alt. 3a & Alt. 3b \\
\hline Attachment to the land & Average & Good & Good & Bad & Bad \\
\hline & Source: Author's own compilation. & &
\end{tabular}

\subsection{Multi-Criteria Impact Matrix}

The MCIM shows all the relevant information about the valuations made in a synthetic way (Table 14). This structuring of the information allows for concise comparisons between alternatives according to each criterion, while facilitating the visualization of the various impacts collected in each alternative by virtue of the type of information used.

Table 14. Multi-Criteria Impact Matrix.

\begin{tabular}{|c|c|c|c|c|c|c|c|c|}
\hline \multirow{4}{*}{ 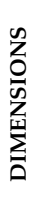 } & \multirow{4}{*}{ 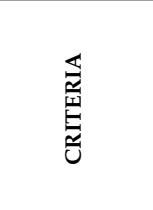 } & \multirow{4}{*}{ 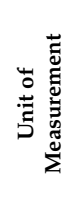 } & \multirow{4}{*}{ 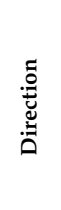 } & \multicolumn{5}{|c|}{ ALTERNATIVES } \\
\hline & & & & \multirow{3}{*}{$\begin{array}{c}\text { BAU } \\
\text { Alt. 1 } \\
\text { Continuation } \\
\text { of Current } \\
\text { Dynamics }\end{array}$} & \multicolumn{2}{|c|}{ New Agrarian Models } & \multicolumn{2}{|c|}{ Promotion of Native Woodland } \\
\hline & & & & & Alt. 2a & Alt. 2b & Alt. 3a & Alt. $3 b$ \\
\hline & & & & & $\begin{array}{l}\text { Medium } \\
\text { Promotion }\end{array}$ & $\begin{array}{l}\text { Intense } \\
\text { Promotion }\end{array}$ & $\begin{array}{l}\text { Alt. 2a and Medium } \\
\text { Promotion of } \\
\text { Native Woodland }\end{array}$ & $\begin{array}{l}\text { Alt. 2a and Intense } \\
\text { Promotion of } \\
\text { Native Woodland }\end{array}$ \\
\hline \multirow{2}{*}{ 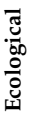 } & Biodiversity & Index & Max & 245,383 & 246,732 & 247,992 & 268,025 & 273,549 \\
\hline & Landscape & Index & Max & $3,387,206$ & $3,392,183$ & $3,397,733$ & $3,774,555$ & $3,873,750$ \\
\hline \multirow{2}{*}{ 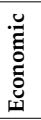 } & $\begin{array}{l}\text { Agrarian } \\
\text { income }\end{array}$ & $€$ & Max & $367,028 €$ & $459,295 €$ & $461,120 €$ & $440,515 €$ & $435,643 €$ \\
\hline & Public cost & $€$ & Min & $379,429 €$ & $416,259 €$ & $426,565 €$ & $561,801 €$ & $599,444 €$ \\
\hline \multirow{2}{*}{ 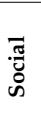 } & $\begin{array}{c}\text { Local } \\
\text { consumption }\end{array}$ & Qual. & Max & Quite bad & Quite good & Good & Quite good & Quite good \\
\hline & $\begin{array}{l}\text { Attachment } \\
\text { to the land }\end{array}$ & Qual. & Max & Average & Good & Good & Bad & Bad \\
\hline
\end{tabular}

Source: Author's own compilation.

Among the numerous existing multi-criteria aggregation methods (for example, [98]), NAIADE (Novel Approach to Imprecise Assessment and Decision Environments) has been used to identify significant differences between the alternatives and order them. This method has certain characteristics $[99,100]$ that are appropriate to the analysis of the case study addressed. In the first place, it allows for the use of information of different types, both qualitative and quantitative (cardinal, stochastic, fuzzy), thus facilitating the integration of uncertainty in the model. Second, unlike other methods, NAIADE gives equal weight to each criterion, so that in our case the ecological, economic, and social dimensions linked to agricultural multifunctionality have the same relative importance. Finally, NAIADE also allows the completion of the so-called equity matrix (Section 4.3), which reflects the degree of acceptance that stakeholders have with respect to the alternatives evaluated and which constitutes an element that facilitates the analysis of conflict.

The NAIADE process, however, requires the definition of the thresholds of indifference and preference that establish the distances between two values of the same alternative. The threshold of indifference is the maximum difference between the values of the same criterion for two different alternatives that does not establish any difference between the two (under this criterion). On the other hand, the threshold of preference is the minimum difference between values of the same criterion for two different alternatives that make one alternative preferred to the other (under this criterion). NAIADE establishes four thresholds: indifference $(\mu=)$, weak indifference $(\mu \approx)$, preference/rejection $(\mu>; \mu<)$ and strong preference/strong rejection $(\mu>>; \mu<<)[45,100]$.

The thresholds of preference and indifference in qualitatively assessed criteria are automatically established by NAIADE. The thresholds of the quantitatively valued criteria were, however, established 
(a) following that established in previous works [101,102]; (b) according to the maximum and minimum values of the different criteria and (c) according to the information obtained in the participatory process. Preference thresholds in quantitative criteria were established as follows: (a) Biodiversity, indifference $(\mu=1000)$, weak indifference $(\mu \approx 4000)$, preference/rejection $(\mu>; \mu<5000)$ and strong preference/strong rejection $(\mu>>; \mu<<8000)$; (b) Landscape, indifference $(\mu=400)$, weak indifference $(\mu \approx 4000)$, preference/rejection $(\mu>; \mu<6000)$ and strong preference/strong rejection ( $\mu>>$; $\mu<<10,000)$; (c) Agrarian income, indifference $(\mu=1000 €)$, weak indifference $(\mu \approx 15,000 €)$, preference/rejection $(\mu>; \mu<25,000 €)$ and strong preference/strong rejection $(\mu>>; \mu<<40,000 €)$; (d) Public cost, indifference $(\mu=5000 €)$, weak indifference $(\mu \approx 25,000 €)$, preference/rejection $(\mu>$; $\mu<50,000 €)$ and strong preference/strong rejection $(\mu>>; \mu<<70,000 €)$.

In operational terms, NAIADE is an outranking method whose aggregation procedure consists of the following [99]: (1) pairwise comparison of alternatives through preference relationships (pre-defined thresholds of indifference and preference); (2) calculation of preference intensity indices, which indicates how much better or worse an alternative is with respect to another; (3) aggregation of preference intensity indices and calculation of the indices $\phi+$ and $\phi-$, that indicate how much better a certain alternative is compared to the rest and how much worse, respectively; (4) obtaining the ranking of alternatives according to the comparison between $\phi+$ and $\phi-$, which is reflected as the intersection between both indices. This intersection is interpreted as a classification of alternatives, from most to least adequate.

\subsection{Equity Matrix}

The equity matrix is based on both the institutional analysis and the information collected during the participatory process, and shows the level of acceptance that each group of stakeholders expresses with each proposed alternative (Table 15). The degree of acceptance ranges from 1 to 9 , with 1 being the value that reflects being in absolute disagreement and 9 the value of being in absolute agreement. This matrix is therefore the basis of social evaluation and is a key input of conflict analysis.

Table 15. Equity matrix.

\begin{tabular}{ccccccc}
\hline \multirow{2}{*}{ Group of Stakeholders } & Stakeholders & \multicolumn{5}{c}{ Alternatives } \\
\cline { 3 - 7 } & & Alt. 1 & Alt. 2a & Alt. 2b & Alt. 3a & Alt. 3b \\
\hline \multirow{3}{*}{ Institutional } & GPC-Ecological positions & 3 & 6 & 6 & 7 & 9 \\
& GPC-Traditional positions & 5 & 6 & 6 & 3 & 1 \\
& City Council of Mutriku & 4 & 8 & 9 & 8 & 8 \\
\hline \multirow{2}{*}{ Technical } & Debemen, HAZI, OCA, Geoparke & 4 & 7 & 8 & 8 & 8 \\
& EHNE Union & 4 & 7 & 8 & 7 & 5 \\
\hline \multirow{2}{*}{ Economic } & ENBA Union & 6 & 7 & 7 & 6 & 5 \\
\hline \multirow{2}{*}{ Social groups } & Traditional farmers & 4 & 6 & 6 & 3 & 2 \\
& Innovative farmers & 4 & 8 & 9 & 8 & 8 \\
\hline
\end{tabular}

Source: Author's own compilation.

\section{Results}

\subsection{Technical Evaluation}

According to the technical evaluation and the criteria used, the most favorable alternatives are $2 \mathrm{~b}$ (C in Table 16) "Intense promotion of new agrarian models" and 3b (E in Table 16) "New agrarian models and intense promotion of the autochthonous forest". Then, in a second degree of suitability, we have Alternative 2a (B in Table 16) "Medium promotion of new agrarian models" and 3a (D in 
Table 16) "New agrarian models and medium promotion of the autochthonous forest (within the Arno SAC)". Finally, Table 16 shows that the least favorable alternative is Alternative 1 (A in Table 16) "Maintain the current dynamics (BAU)".

Table 16. Indices $\phi+$ and $\phi-$ and their intersection.

\begin{tabular}{|c|c|c|c|c|c|c|c|}
\hline \multicolumn{2}{|c|}{$\phi+$} & \multicolumn{2}{|c|}{$\mathbf{\phi}-$} & \multicolumn{2}{|c|}{ Intersection } & \multicolumn{2}{|c|}{ Alternatives } \\
\hline \multirow[t]{2}{*}{0.50} & $\mathrm{E}$ & 0.24 & $\mathrm{C}$ & & & A & A.1 \\
\hline & $\downarrow$ & & $\downarrow$ & $\mathrm{C}$ & E & B & A. $2 \mathrm{a}$ \\
\hline \multirow[t]{2}{*}{0.41} & $\mathrm{D}$ & 0.24 & B & $\downarrow$ & $\downarrow$ & $\mathrm{C}$ & A. $2 b$ \\
\hline & $\downarrow$ & & $\downarrow$ & B & $\mathrm{D}$ & $\mathrm{D}$ & A.3a \\
\hline \multirow[t]{2}{*}{0.39} & $\mathrm{C}$ & 0.38 & $\mathrm{E}$ & $\downarrow$ & & $\mathrm{E}$ & A. $3 b$ \\
\hline & $\downarrow$ & & $\downarrow$ & $\mathrm{A}$ & & & \\
\hline \multirow[t]{2}{*}{0.38} & B & 0.43 & D & & & & \\
\hline & $\downarrow$ & & $\downarrow$ & & & & \\
\hline 0.19 & A & 0.65 & A & & & & \\
\hline
\end{tabular}

Source: Author's own compilation.

In the two alternatives that enjoy the highest degree of suitability ( $2 b$ and $3 b)$, a change is proposed in land use towards the promotion of innovative and job-creating agriculture and livestock rearing, although the intensity of this use varies according to the chosen alternative. With respect to the current situation, in Alternative $3 b$, the forest policy, with a greater ecological component, also varies, as it carries high valuations in the criteria of landscape and biodiversity.

To test the robustness of the model, sensitivity analysis was also carried out. For this, variations were introduced in the initial parameters with the intention of reflecting the uncertainty and existing risk in the complex socio-ecological systems. Specifically, different variations were made in the compensation $(\gamma)$ and credibility $(\alpha)$ indices, in line with what has been done in other research works $[95,103,104]$. As the results did not vary significantly after introducing the mentioned variations, we assured that the results obtained are robust.

The ranking of alternatives, however, not only depends on technical elements such as the selected indicators and the method of aggregation used, but also on the structuring of the problem under study. That is why the participation of stakeholders throughout the process is essential for the control of the results and to favor transparency $[78,105]$. Thus, the results of the technical evaluation were contrasted with the stakeholders in the third workshop (Section 3.2). In fact, the opinions of the stakeholders reflected divergent positions regarding the two technically better positioned alternatives.

\subsection{Social Evaluation: Narrowing the Conflict Analysis}

Social evaluation shows the position of the stakeholders in relation to each alternative, as well as the coalitions that can be formed between different stakeholders with respect to the alternatives evaluated. Thus, social evaluation contributes towards analyzing, in terms of conflict, the existing disparities between stakeholders with respect to the alternatives. This analysis also contributes to the search for so-called "compromise solutions" [44,45,106].

Based on the equity matrix (Section 4.3), NAIADE calculates a coalition dendrogram showing the similarities and disagreements among the different stakeholders and concluding which alternative each coalition considers most favorable, as well as considering alternatives with a lower degree of acceptance. The degree of similarity defines the number of coalitions among stakeholders depending on their preferences with respect to the alternatives (i.e., the lowest similarity index outcome is just one coalition and the highest can be equal to the number of stakeholders). In line with other researches in this field $[53,56,57,84,107]$, in our case the coalition dendrogram has been calculated for a similarity index of 0.68 , whose outcome is shown in Table 17.

The results of the analysis lead us to conclude that there are three main coalitions. On the one hand, the coalition of the two agrarian unions accepts Alternative $2 b$ as being more desirable and 
Alternative 1 as being the least desirable. The second coalition formed by the traditional positions of the GPC and traditional farmers prioritizes Alternative $2 a$, with $3 b$ being the least desirable for them. Finally, the stakeholders of the most numerous coalition, formed by the ecological positions of the GPC, the City Council of Mutriku, the agents of rural development, the innovative farmers and the groups representing ecology and leisure, agree that Alternative $3 b$ is the most desirable, while Alternatives $2 a$ and 1 are the least preferred, respectively, and are vetoed by this coalition.

Table 17. Coalitions of stakeholders with respect to the alternatives evaluated.

\begin{tabular}{cccc}
\hline & \multicolumn{3}{c}{ Coalitions of Stakeholders } \\
\cline { 2 - 4 } Degree of Preference & $\begin{array}{c}\text { EHNE Union, } \\
\text { ENBA Union }\end{array}$ & $\begin{array}{c}\text { GPC-Traditional } \\
\text { Positions, } \\
\text { Traditional Farmers }\end{array}$ & $\begin{array}{c}\text { GPC-Ecological Positions, City } \\
\text { Council of Mutriku, Debemen, HAZI, } \\
\text { OCA, Geoparke, Innovative Farmers, } \\
\text { Ecologist Groups, Leisure Groups }\end{array}$ \\
\hline \multirow{2}{*}{$\begin{array}{c}\text { Degree of } \\
\text { preference }\end{array}$} & A 2b & A 2a & A 3b \\
& A 2a & A 2b & A 3a \\
& A 3a & A 1 $~$ & A 2b \\
& A 3b & A 3a & A 2a (vetoed) \\
& A 1 1 (vetoed)
\end{tabular}

Source: Author's own compilation.

According to this analysis, Alternative $2 b$ is the preferred alternative for the agrarian unions and the second most desirable for the traditional position of the GPC, while it occupies third position for the most numerous coalition of stakeholders. Alternative $3 b$, on the other hand, despite being equally suitable according to the technical evaluation, presents a high risk of social conflict, given that it presents more confronted positions among the stakeholders. Both the traditional positions of the GPC and the traditional farmers consider it the worst of the alternatives and in fact they have manifested publicly against it on numerous occasions in the last few years, when proposals for new forestry policies made by the more ecological positions of the GPC have been placed.

\subsection{Overall Results}

Based on both the technical and social evaluations, three main results have been reached. First, the worst alternative is the continuation of current dynamics (BAU). Continuing with the progressive abandonment of agriculture and livestock is the least appropriate of the options under any of the assumptions analyzed.

Second, of all the alternatives evaluated, the most appropriate are $2 b$ and $3 b$; both alternatives involve renewing and reactivating the current agro-livestock model towards a more ecological and higher quality agriculture and livestock rearing. Alternative $2 \mathrm{~b}$ proposes an intense promotion of new agrarian models, such as organic farming, greenhouse agriculture, fruit, and livestock farms aimed at producing high quality products. Alternative $3 \mathrm{~b}$, meanwhile, implies a more moderate enhancement of this agrarian model (one less livestock farm) and a substantial change in the forestry model, promoting native species in both the Arno SAC and the rest of the municipality.

In Alternative $2 b$, the economic and social dimensions are enhanced to the detriment of greater contributions of an ecological nature, while in $3 b$ the opposite happens. Alternative $2 b$ obtains better valuation in the economic and social dimensions, especially in attachment to the land and in public cost (an increase of 47,000 euros with respect to the current situation). This alternative ultimately proposes a model of rural development in which the social function prevails; a live rural environment is promoted, in which new agrarian practices allow for the maintenance of ecological balance and at the same time enhance human presence in rural areas, but without substantial changes in forest policy, which continues to favor the proliferation of conifers. On the contrary, Alternative $3 \mathrm{~b}$ achieves worse valuation in the criteria that reflect the economic and social dimensions but much better in the ecological criteria (biodiversity and landscape); the public cost of this alternative would amount to 220,000 euros. 
This second alternative proposes a greater environmental value, where the predominance of ecological criteria derives from a hypothetical new forest policy, and where human presence would be less than in Alternative $2 b$ even though it would form a landscape better valued by the majority of the population by diminishing the presence of conifer plantations.

Finally, between the two most suitable alternatives under the technical evaluation ( $2 b$ and $3 b)$, Alternative $2 b$ is the most appropriate insofar as it presents less faced positions among the stakeholders and, therefore, a priori a lower degree of social conflict. From this point of view, we can consider Alternative $2 \mathrm{~b}$ as the compromise solution.

\section{Discussion and Conclusions}

The crisis of the traditional agrarian model and the change of land uses associated with it during the last decades show the need to look for new models of rural development. The multifunctionality of rural spaces raises the question of what sectors, functions and dimensions of the territory need to be promoted, taking into account also that rural land is a limited resource. Thus, policy makers often face the challenge of promoting certain land uses to the detriment of others.

In this context, our case study has shown, first, that the SMCE is a sound methodological framework for the evaluation of rural development alternatives at the municipal level. The various development alternatives have been valued considering the different functions of the rural environment, both economic, ecological and social, which has made it possible to consider the multifunctionality of these territories and evaluate the development alternatives properly. In this process, we have also worked with values of distinctly different natures, cartography, indicators and measurements in different units, and using different calculation procedures, all of which have allowed us to properly incorporate the technical incommensurability [44,45] in the evaluation process.

From the participatory process carried out, the following can also be concluded: the existence of stakeholders with diverse and even conflicting interests and opinions on the rural development model to be implemented and the subsequent planning of the land. However, during this participatory process, the risk of latent conflict between different stakeholders also surfaced, an issue reflected in the social evaluation. This is a case study, therefore, in which social incommensurability $[44,45]$ has also been adequately incorporated in the evaluation. In fact, the fuzzy environment implied by rural planning has been properly faced by NAIADE, allowing to combine both qualitative and quantitative diverse information.

In addition, participation during the process was active and dynamic, and the contributions of the stakeholders were decisive. The stakeholders contributed to the definition of evaluation criteria, but above all to the construction of alternatives, given that those initially proposed by the team of evaluators were substantially modified as result of the second focus group. This highlights the importance of incorporating local, and not only scientific, knowledge into participatory processes by determining the evaluation object as has been the case in other experiences [72-74]. This has probably been the main lesson learnt during the evaluation process. It also shows that the participatory process was efficient and transparent, and contributes to its results having greater legitimacy and social acceptance, as has been the case in other studies [31,78,79].

This has led us to conclude that the participatory process followed within a bottom-up approach at the local scale is appropriate. However, doubts arise when real participative processes might be applied in a larger scale than local. To our knowledge, there is just one real world application of the SMCE at the national level [108], which calls into question, not the SMCE as a methodological approach, but rather the scope of participatory processes. So, a challenge within the SMCE context would be to consistently integrate participatory processes in a larger scale than local.

Regarding the findings, secondly, our case study has revealed that the worst alternative is BAU (Alternative 1), so it is necessary to propose policies that quickly reverse this trend in favor of a comprehensive revitalization of the agricultural and livestock sector. Jointly, the analysis undertaken has suggested that the most suitable alternatives are $2 \mathrm{~b}$ and $3 \mathrm{~b}$. These two alternatives, however, show 
two different models of rural development, both within the paradigm of multifunctionality but each enhancing different dimensions of it.

This case is therefore another example of the existence of trade-offs when implementing multifunctionality from the point of view of planning. As evidenced in other cases $[23,109,110]$, it is difficult to avoid these conflicts between uses when translating multifunctionality into territorial planning, given that at the time of planning land uses, the vocation of a particular land use is enhanced towards a certain function (economic, environmental, social) to the detriment of other uses and/or functions. That is, in Alternative $2 b$, land uses are promoted for agricultural activity, while in $3 b$ this empowerment is less while at the same time the land for forest use is destined to favor autochthonous forest to the detriment of conifers. This reduction of conifers would clearly better environmental performance in the region, with benefits in watersheds [111]. However, regardless of the direction to be taken by forestry policy, Mutriku must urgently take measures that reverse the decline of agricultural and livestock activity, given that it has been shown that continuing with the current dynamics (BAU) is the worst possible alternative and that, at the same time, the promotion of a new agrarian model is needed (as seen in both Alternative $2 b$ and $3 b$ ). However, the case of Mutriku is not particular to the Basque Country as agricultural regression has become widespread during the last few decades [26].

The third conclusion is related to the conflicting values, and consequently to governance and decision-making. Of the two most suitable alternatives according to the technical evaluation, from the social point of view, solution $2 \mathrm{~b}$ must be considered as the compromise solution. On the contrary, however, Alternative $3 \mathrm{~b}$ presents a greater risk of social conflict. This social dilemma between both alternatives is due to the fact that forestry policy has provoked deep debates and disagreements in Gipuzkoa during the last few years, and it continues to be a subject that provokes confrontation between stakeholders with conflicting opinions.

The social analysis reveals the latent conflict that exists in Gipuzkoa and the entire Cantabrian coast, evidencing the divergent positions on the coniferous forests and their proliferation in recent decades [112]. These discrepant positions are basically between the owners of rural land who defend the current forestry model with the aim of making that land profitable and the social groups that value the rural environment for its ecological and landscape values and as a place for leisure and recreation. However, the position of public institutions in this respect is mixed, depending, on the one hand, on the institutions themselves and on the scope of their competences and, on the other hand, on the divergent positions of policy makers within each institution.

In our case study, it is worth noting the strength of the first group, that of the owners of the rural land, in a context where most of this land is private. In fact, the hypothetical conversion of coniferous to native species depends ultimately on the decision of the owner of the land, regardless of any financial assistance granted. It also highlights the power conflict that exists within the GPC to the extent that stakeholders in the same institution hold conflicting positions with regard to forestry policy (i.e., traditional versus ecological positions). This institution has not followed the same policy line in recent years, and in this dispute between traditional and ecological positions, it seems that the former impose themselves more often on the latter, given that their greater resources have slowed the most daring ecological initiatives of this second group. The power asymmetry between the stakeholders becomes clear [113]: not all the stakeholders have the same power during the participatory process or especially in the decision-making process.

In this regard, the fact that the City Council of Mutriku has the legal power to approve the MLUP must be pointed out. Although the findings derived from the whole evaluation process are realistic, the recent change of the political cycle in Mutriku has led to an impasse in the application of its results. The findings of the SMCE carried out must be an input for the MLUP, but the MLUP is still in the process of being elaborated after the governing body changed. This, however, does not call into question the validity of the participatory process due to the reasons given above, although it may call into question its effectiveness to the extent that some stakeholders have greater decision-making power over the process outcome and alternatives evaluated. 
Author Contributions: I.E. designed the research and methodological approach, and he wrote the majority of the manuscript including the revised version. I.B.-R. conducted fieldwork and undertook the analysis. O.G. contributed to the analysis and provided suggestions for improvements. All authors participated in the focus groups within the participative process. All authors read and approved the final manuscript.

Funding: This research was funded by Spanish Ministry of Economy and Competitiveness (MINECO), grant number AGL2013-48361-C2-1-R, and by University of the Basque Country (UPV/EHU), grant number GIU 10/07.

Acknowledgments: The authors wish to thank all the stakeholders interviewed for their participation. They would also like to thank three anonymous reviewers for their comments and suggestions. The usual disclaimer applies.

Conflicts of Interest: The authors declare no conflict of interest.

\section{References}

1. Primdahl, J.; Andersen, E.; Swaffield, S.; Kristensen, L. Intersecting dynamics of agricultural structural change and urbanisation within European rural landscapes: Change patterns and policy implications. Landsc. Res. 2013, 38, 799-817. [CrossRef]

2. Olsson, E.G.A.; Kerselaers, E.; Søderkvist Kristensen, L.; Primdahl, J.; Rogge, E.; Wästfelt, A. Peri-Urban Food Production and Its Relation to Urban Resilience. Sustainability 2016, 8, 1340. [CrossRef]

3. Verhoeve, A.; Dewaelheyns, V.; Kerselaers, E.; Rogge, E.; Gulinck, H. Virtual farmland: Grasping the occupation of agricultural land by non-agricultural land uses. Land Use Policy 2015, 42, 547-556. [CrossRef]

4. Bryden, J.; Bollman, R. Rural employment in industrialised countries. Agric. Econ. 2000, 22, 185-197. [CrossRef]

5. Power, A.G. Ecosystem services and agriculture: Tradeoffs and synergies. Philos. Trans. R. Soc. Lond. B Biol. Sci. 2010, 365, 2959-2971. [CrossRef] [PubMed]

6. Ananda, J.; Herath, G. A critical review of multi-criteria decision making methods with special reference to forest management and planning. Ecol. Econ. 2009, 68, 2535-2548. [CrossRef]

7. Kangas, A.; Laukkanen, S.; Kangas, J. Social choice theory and its applications in sustainable forest management-A review. For. Policy Econ. 2006, 9, 77-92. [CrossRef]

8. Daugstad, K.; Rønningen, K.; Skar, B. Agriculture as an upholder of cultural heritage? Conceptualizations and value judgements-A Norwegian perspective in international context. J. Rural Stud. 2006, 22, 67-81. [CrossRef]

9. Huang, J.; Tichit, M.; Poulot, M.; Darly, S.; Li, S.; Petit, C.; Aubry, C. Comparative review of multifunctionality and ecosystem services in sustainable agriculture. J. Environ. Manag. 2015, 149, 138-147. [CrossRef] [PubMed]

10. Swinton, S.M.; Lupi, F.; Robertson, G.P.; Hamilton, S.K. Ecosystem services and agriculture: Cultivating agricultural ecosystems for diverse benefits. Ecol. Econ. 2007, 64, 245-252. [CrossRef]

11. Sayadi, S.; González-Roa, M.C.; Calatrava-Requena, J. Public preferences for landscape features: The case of agricultural landscape in mountainous Mediterranean areas. Land Use Policy 2009, 26, 334-344. [CrossRef]

12. Horlings, L.G.; Marsden, T.K. Exploring the 'New Rural Paradigm' in Europe: Eco-economic strategies as a counterforce to the global competitiveness agenda. Eur. Urban Reg. Stud. 2014, 21, 4-20. [CrossRef]

13. Aubry, C.; Ramamonjisoa, J.; Dabat, M.; Rakotoarisoa, J.; Rakotondraibe, J.; Rabeharisoa, L. Urban agriculture and land use in cities: An approach with the multi-functionality and sustainability concepts in the case of Antananarivo (Madagascar). Land Use Policy 2012, 29, 429-439. [CrossRef]

14. Manson, S.M.; Jordan, N.R.; Nelson, K.C.; Brummel, R.F. Modeling the effect of social networks on adoption of multifunctional agriculture. Environ. Model. Softw. 2016, 75, 388-401. [CrossRef] [PubMed]

15. Morgan, S.L.; Marsden, T.; Miele, M.; Morley, A. Agricultural multifunctionality and farmers' entrepreneurial skills: A study of Tuscan and Welsh farmers. J. Rural Stud. 2010, 26, 116-129. [CrossRef]

16. Wilson, G.A. From 'weak' to 'strong' multifunctionality: Conceptualising farm-level multifunctional transitional pathways. J. Rural Stud. 2008, 24, 367-383. [CrossRef]

17. Alva-Lizarraga, S.; Refsgaard, K.; Johnson, T.G. Comparative analysis of agriculture and rural policies in Västerbotten and Hordaland using the POMMARD-model. Food Econ. Acta Agric. Scand. Sect. C 2011, 8 , 142-160. [CrossRef]

18. Bryden, J.M.; Efstratoglou, S.; Ferenczi, T.; Knickel, K.; Johnson, T.; Refsgaard, K.; Thomson, K.J. Towards Sustainable Rural Regions in Europe: Exploring Inter-Relationships between Rural Policies, Farming, Environment, Demographics, Regional Economies and Quality of Life Using System Dynamics; Routledge: London, UK; New York, NY, USA, 2011. 
19. European Commission. Contribution of the European Community on the Multifunctional Character of Agriculture? Info-Paper; Directorate General of Agriculture, European Commission: Brussel, Belgium, 1999.

20. OECD. Multifunctionality: Towards an Analytical Framework; OECD Publications Service: Paris, France, 2001.

21. Marsden, T.; Sonnino, R. Rural development and the regional state: Denying multifunctional agriculture in the UK. J. Rural Stud. 2008, 24, 422-431. [CrossRef]

22. Van der Ploeg, J.D.; Marsden, T. Unfolding Webs: The Dynamics of Regional Rural Development; Royal Van Gorcum: Assen, The Netherlands, 2008.

23. Rega, C.; Bonifazi, A. Strategic Environmental Assessment and spatial planning in Italy: Sustainability, integration and democracy. J. Environ. Plan. Manag. 2014, 57, 1333-1358. [CrossRef]

24. Salazar-Ordóñez, M.; Sayadi, S. Environmental care in agriculture: A social perspective. J. Agric. Environ. Ethics 2011, 24, 243-258. [CrossRef]

25. Vrebos, D.; Bampa, F.; Creamer, R.E.; Gardi, C.; Ghaley, B.B.; Jones, A.; Rutgers, M.; Sandén, T.; Staes, J.; Meire, P. The Impact of Policy Instruments on Soil Multifunctionality in the European Union. Sustainability 2017, 9, 407. [CrossRef]

26. Malagón, E. Multifuncionalidad e Instrumentos de Política Agraria. El Caso de la Política Ambiental en la Comunidad Autónoma del País Vasco. Ph.D. Thesis, HEGOA, University of the Basque Country, Leioa, Spain, 2009.

27. González-Moralejo, S.A.; Estruch Sanchís, F. The Common Agricultural Policy and the Increased Competitiveness of Spanish Regional Agriculture. J. Agric. Sci. 2017, 9, 74. [CrossRef]

28. Steinhäußer, R.; Siebert, R.; Steinführer, A.; Hellmich, M. National and regional land-use conflicts in Germany from the perspective of stakeholders. Land Use Policy 2015, 49, 183-194. [CrossRef]

29. Julien, B.; Lammertz, M.; Barbier, J.; Jen, S.; Ballesteros, M.; Bovis, C.d.; Krott, M. Voicing Interests and Concerns: NATURA 2000: An ecological network in conflict with people. For. Policy Econ. 2000, 1, 357-366.

30. Dearden, P.; Bennett, M.; Johnston, J. Trends in global protected area governance, 1992-2002. Environ. Manag. 2005, 36, 89-100. [CrossRef] [PubMed]

31. Reed, M.S. Stakeholder participation for environmental management: A literature review. Biol. Conserv. 2008, 141, 2417-2431. [CrossRef]

32. Ribot, J. Democratic Decentralization of Natural Resources: Institutionalizing Popular Participation; World Resources Institute: Washington, DC, USA, 2002.

33. Pretty, J. Social capital and the collective management of resources. Science 2003, 302, 1912-1914. [CrossRef] [PubMed]

34. O'Farrell, P.J.; Anderson, P.M. Sustainable multifunctional landscapes: A review to implementation. Curr. Opin. Environ. Sustain. 2010, 2, 59-65. [CrossRef]

35. Kok, K.; Biggs, R.O.; Zurek, M. Methods for developing multiscale participatory scenarios: Insights from southern Africa and Europe. Ecol. Soc. 2007, 12, 8. [CrossRef]

36. Pinto-Correia, T.; Gustavsson, R.; Pirnat, J. Bridging the gap between centrally defined policies and local decisions-Towards more sensitive and creative rural landscape management. Landsc. Ecol. 2006, 21, 333-346. [CrossRef]

37. Stenseke, M. Local participation in cultural landscape maintenance: Lessons from Sweden. Land Use Policy 2009, 26, 214-223. [CrossRef]

38. Shucksmith, M. Disintegrated rural development? Neo-endogenous rural development, planning and place-shaping in diffused power contexts. Sociol. Rural. 2010, 50, 1-14. [CrossRef]

39. Renting, H.; Rossing, W.A.H.; Groot, J.C.J.; Van der Ploeg, J.D.; Laurent, C.; Perraud, D.; Stobbelaar, D.J.; Van Ittersum, M.K. Exploring multifunctional agriculture. A review of conceptual approaches and prospects for an integrative transitional framework. J. Environ. Manag. 2009, 90, S112-S123. [CrossRef] [PubMed]

40. Beinat, E.; Nijkamp, P. Multicriteria Analysis for Land-Use Management; Kluwer Academic Publishers: Dordrecht, The Netherlands, 1998.

41. Roy, B. Paradigms and challenges. In Multiple Criteria Decision Analysis: State of the Art Surveys; Figueira, J., Greco, S., Ehrgott, M., Eds.; Springer: Boston, MA, USA, 2005; pp. 3-24.

42. Cerreta, M. Thinking through complex values. In Making Strategies in Spatial Planning; Cerreta, M., Concilio, C., Monno, V., Eds.; Springer: Berlin, Germany, 2010; pp. 381-404.

43. Prato, T. Evaluating land use plans under uncertainty. Land Use Policy 2007, 24, 165-174. [CrossRef] 
44. Munda, G. Social multi-criteria evaluation: Methodological foundations and operational consequences. Eur. J. Oper. Res. 2004, 158, 662-677. [CrossRef]

45. Munda, G. Social Multi-Criteria Evaluation for a Sustainable Economy; Springer: Berlin, Germany, 2008.

46. Martínez-Alier, J.; Munda, G.; O'Neill, J. Weak comparability of values as a foundation for ecological economics. Ecol. Econ. 1998, 26, 277-286. [CrossRef]

47. Rega, C. (Ed.) Landscape Planning and Rural Development: Key Issues and Options towards Integration; Springer: Cham, Germany, 2014.

48. Lienert, J.; Schnetzer, F.; Ingold, K. Stakeholder analysis combined with social network analysis provides fine-grained insights into water infrastructure planning processes. J. Environ. Manag. 2013, 125, 134-148. [CrossRef] [PubMed]

49. Grima, N.; Singh, S.J.; Smetschka, B. Decision making in a complex world: Using OPTamos in a multi-criteria process for land management in the Cuitzmala watershed in Mexico. Land Use Policy 2017, 67, $73-85$. [CrossRef]

50. Martínez-Sastre, R.; Ravera, F.; González, J.; Santiago, C.L.; Bidegain, I.; Munda, G. Mediterranean landscapes under change: Combining social multicriteria evaluation and the ecosystem services framework for land use planning. Land Use Policy 2017, 67, 472-486. [CrossRef]

51. Pearson, L.J.; Park, S.; Harman, B.; Heyenga, S. Sustainable land use scenario framework: Framework and outcomes from peri-urban South-East Queensland, Australia. Landsc. Urban Plan. 2010, 96, 88-97. [CrossRef]

52. Oikonomou, V.; Dimitrakopoulos, P.G.; Troumbis, A.Y. Incorporating ecosystem function concept in environmental planning and decision making by means of multi-criteria evaluation: The case-study of Kalloni, Lesbos, Greece. Environ. Manag. 2011, 47, 77-92. [CrossRef] [PubMed]

53. Etxano, I.; Garmendia, E.; Pascual, U.; Hoyos, D.; Díez, M.; Cadiñanos, J.A.; Lozano, P.J. A participatory integrated assessment approach for Natura 2000 network sites. Environ. Plan. C Gov. Policy 2015, 33, 1207-1232. [CrossRef]

54. Tarrason, D.; Ortiz, O.; Alcaniz, J.M. A multi-criteria evaluation of organic amendments used to transform an unproductive shrubland into a Mediterranean dehesa. J. Environ. Manag. 2007, 82, 446-456. [CrossRef] [PubMed]

55. Siciliano, G. Social multicriteria evaluation of farming practices in the presence of soil degradation. A case study in Southern Tuscany, Italy. Environ. Dev. Sustain. 2009, 11, 1107. [CrossRef]

56. Acosta, M.; Corral, S. Participatory multi-criteria assessment of forest planning policies in conflicting situations: The case of tenerife. Forests 2015, 6, 3946-3969. [CrossRef]

57. Lutz, J.; Smetschka, B.; Grima, N. Farmer Cooperation as a Means for Creating Local Food SystemsPotentials and Challenges. Sustainability 2017, 9, 925. [CrossRef]

58. Gamboa, G. Social multi-criteria evaluation of different development scenarios of the Aysén region, Chile. Ecol. Econ. 2006, 59, 157-170. [CrossRef]

59. City Council of Mutriku. Revision of Subsidiary Rules for Municipal Planning of Mutriku (GHI-144/05-P05; Official Bulletin of Gipuzkoa, No. 148, the 7th of August 2006; City Council of Mutriku: Mutriku, Spain, 2006.

60. Eustat. Available online: http:/ / eustat.eus (accessed on 3 May 2018).

61. Giannakis, E.; Bruggeman, A. The highly variable economic performance of European agriculture. Land Use Policy 2015, 45, 26-35. [CrossRef]

62. Aldanondo Ochoa, A.M.; Casanovas Oliva, V.; Almansa Sáez, C. Explaining farm succession: The impact of farm location and off-farm employment opportunities. Span. J. Agric. Res. 2007, 5, 214-225. [CrossRef]

63. European Commission, Directorate General for Agriculture and Rural Development. Other Gainful Activities: Pluriactivity and Farm Diversification in EU-27; Technical Report; European Commission, Directorate General for Agriculture and Rural Development: Brussels, Belgium, 2008.

64. Alasia, A.; Weersink, A.; Bollman, R.D.; Cranfield, J. Off-farm labour decision of Canadian farm operators: Urbanization effects and rural labour market linkages. J. Rural Stud. 2009, 25, 12-24. [CrossRef]

65. Giannakis, E.; Efstratoglou, S.; Antoniades, A. Off-Farm Employment and Economic Crisis: Evidence from Cyprus. Agriculture 2018, 8, 41. [CrossRef]

66. Carnoye, L.; Lopes, R. Participatory Environmental Valuation: A Comparative Analysis of Four Case Studies. Sustainability 2015, 7, 9823-9845. [CrossRef]

67. Videira, N.; Antunes, P.; Santos, R.; Lobo, G. Public and stakeholder participation in European water policy: A critical review of project evaluation processes. Environ. Policy Gov. 2006, 16, 19-31. [CrossRef] 
68. Deneulin, S.; Shahani, L. An Introduction to the Human Development and Capability Approach: Freedom and Agency; Earthscan: London, UK, 2009.

69. Reed, M.S.; Graves, A.; Dandy, N.; Posthumus, H.; Hubacek, K.; Morris, J.; Prell, C.; Quinn, C.H.; Stringer, L.C. Who's in and why? A typology of stakeholder analysis methods for natural resource management. J. Environ. Manag. 2009, 90, 1933-1949. [CrossRef] [PubMed]

70. Scholes, R.; Biggs, R. A biodiversity intactness index. Nature 2005, 434, 45. [CrossRef] [PubMed]

71. Patel, M.; Kok, K.; Rothman, D.S. Participatory scenario construction in land use analysis: An insight into the experiences created by stakeholder involvement in the Northern Mediterranean. Land Use Policy 2007, 24, 546-561. [CrossRef]

72. Raymond, C.M.; Fazey, I.; Reed, M.S.; Stringer, L.C.; Robinson, G.M.; Evely, A.C. Integrating local and scientific knowledge for environmental management. J. Environ. Manag. 2010, 91, 1766-1777. [CrossRef] [PubMed]

73. Stringer, L.C.; Reed, M.S. Land degradation assessment in southern Africa: Integrating local and scientific knowledge bases. Land Degrad. Dev. 2007, 18, 99-116. [CrossRef]

74. Whitfield, S.; Geist, H.J.; Ioris, A.A. Deliberative assessment in complex socioecological systems: Recommendations for environmental assessment in drylands. Environ. Monit. Assess. 2011, 183, 465-483. [CrossRef] [PubMed]

75. Bergseng, E.; Vatn, A. Why protection of biodiversity creates conflict-Some evidence from the Nordic countries. J. For. Econ. 2009, 15, 147-165. [CrossRef]

76. Rauschmayer, F.; Berghöfer, A.; Omann, I.; Zikos, D. Examining processes or/and outcomes? Evaluation concepts in European governance of natural resources. Environ. Policy Gov. 2009, 19, 159-173. [CrossRef]

77. Schultz, L.; Duit, A.; Folke, C. Participation, adaptive co-management, and management performance in the world network of biosphere reserves. World Dev. 2011, 39, 662-671. [CrossRef]

78. Garmendia, E.; Stagl, S. Public participation for sustainability and social learning: Concepts and lessons from three case studies in Europe. Ecol. Econ. 2010, 69, 1712-1722. [CrossRef]

79. Pahl-Wostl, C.; Mostert, E.; Tàbara, D. The growing importance of social learning in water resources management and sustainability science. Ecol. Soc. 2008, 13, 24. [CrossRef]

80. Salzer, C.; Wallbaum, H.; Lopez, L.F.; Kouyoumji, J.L. Sustainability of Social Housing in Asia: A Holistic Multi-Perspective Development Process for Bamboo-Based Construction in the Philippines. Sustainability 2016, 8, 151. [CrossRef]

81. Tàbara, J.D.; Pahl-Wostl, C. Sustainability learning in natural resource use and management. Ecol. Soc. 2007, 12, 3. [CrossRef]

82. Díez, M.; Etxano, I.; Garmendia, E. Evaluating participatory processes in conservation policy and governance: Lessons from a Natura 2000 pilot case study. Environ. Policy Gov. 2015, 25, 125-138. [CrossRef]

83. Moro, G.; Cassibba, R.; Costantini, A. Focus groups as an instrument to define evaluation criteria: The case of foster care. Evaluation 2007, 13, 340-357. [CrossRef]

84. Garmendia, E.; Gamboa, G.; Franco, J.; Garmendia, J.M.; Liria, P.; Olazabal, M. Social multi-criteria evaluation as a decision support tool for integrated coastal zone management. Ocean Coast. Manag. 2010, 53, 385-403. [CrossRef]

85. Latasa, I.; Lozano, P.J.; Barinaga-Rementeria, I.; Etxano, I.; García, O. Tokiko eskalan balorazio zoogeografikoa egiteko proposamen metodologikoa eta balorazioaren emaitzak. Mutrikuko (Euskal Herria) Hiri Antolamenduko Plan Orokorraren eredua. [The results of a methodological proposal for a zoogeographic evaluation at a local scale. The Municipal Land-Use Plan of Mutriku (Basque Country)]. Lurralde 2017, 40, 193-222.

86. Lozano, P. Bases Para Una Zoogeografía Aplicada: Diseño de una Metodología Geográfica de Atlas de Fauna, Aplicación a los Vertebrados del Sector Nororiental de Guipuzkoa (País Vasco); Herka: Donostia, Spain, 2009.

87. Lozano, P.J.; Cadiñanos, J.A.; Etxano, I. Propuesta de valoración zoogeográfica para la evaluación de los espacios Red Natura 2000, de la CAPV. El ejemplo de Gárate-Santa Bárbara (País Vasco). Polígonos. Rev. Geogr. 2012, 22, 123-149. [CrossRef]

88. Wilson, E. La Diversidad de la Vida; Crítica: Barcelona, Spain, 1994.

89. Cadiñanos, J.A.; Lozano, P.; Quintanilla, V. Propuesta de marco metodológico integrado para la valoración biogeográfica de espacios Red Natura 2000 de la Comunidad Autónoma del País Vasco: El ejemplo de Gárate-Santa Bárbara (Guipúzcoa). Boletín de la Asociación de Geógrafos Españoles 2011, 57, 33-56. 
90. Cadiñanos, J.A.; Meaza, G. Bases Para Una Biogeografía Aplicada. Criterios y Sistemas de Valoración de la Vegetación; Geoforma: Logroño, Spain, 1998.

91. Quintanilla, V.; Lozano, P.J.; Gómez, D.C. Evaluación biogeográfica de las poblaciones más meridionales del bosque mediterráneo chileno con palmas nativas (Jubaea chilensis (Mol.) Baillon). Cuad. Geogr. 2017, 56, 6-25.

92. Lozano, P.J.; Latasa, I. Valoración Biogeográfica de los paisajes del suelo rústico de Mutriku (Guipúzcoa) de cara a su ordenación y gestión. In Análisis Espacial y Representación Geográfica: Innovación y Aplicación; de La Riva, J., Ibarra, P., Montorio, R., Rodríguez, M., Eds.; Universidad de Zaragoza-AGE: Zaragoza, Spain, 2015; pp. 1063-1072.

93. Basque Government. Documento de Objetivos y Medidas de Conservación Para la Designación de la Zona de Especial Conservación Arno (ES2120001); Environment, Territorial Planning, Agriculture and Fishing Department of the Basque Government: Vitoria-Gasteiz, Spain, 2012.

94. Basque Government. Order 3,397 of the Basque Government; Official Bulletin of the Basque Country, No. 141, 24th of July 2013; Basque Government: Vitoria-Gasteiz, Spain, 2013.

95. Monterroso, I.; Binimelis, R.; Rodríguez-Labajos, B. New methods for the analysis of invasion processes: Multi-criteria evaluation of the invasion of Hydrilla verticillata in Guatemala. J. Environ. Manag. 2011, 92, 494-507. [CrossRef] [PubMed]

96. Paneque Salgado, P.; Corral Quintana, S.; Guimarães Pereira, Â.; del Moral Ituarte, L.; Pedregal Mateos, B. Participative multi-criteria analysis for the evaluation of water governance alternatives. A case in the Costa del Sol (Málaga). Ecol. Econ. 2009, 68, 990-1005. [CrossRef]

97. Roca, E.; Gamboa, G.; Tàbara, J.D. Assessing the multidimensionality of coastal erosion risks: Public participation and multicriteria analysis in a Mediterranean coastal system. Risk Anal. 2008, 28, 399-412. [CrossRef] [PubMed]

98. Greco, S.; Figueira, J.; Ehrgott, M. Multiple Criteria Decision Analysis. State of the Arts Survey; Springer: New York, NY, USA, 2005.

99. Joint Research Centre of the European Commission. NAIADE: Manual and Tutorial; Joint Research Centre: Istra, Italy, 1996.

100. Munda, G.; Nijkamp, P.; Rietveld, P. Qualitative multicriteria methods for fuzzy evaluation problems: An tillustration of economic-ecological evaluation. Eur. J. Oper. Res. 1995, 82, 79-97. [CrossRef]

101. Vallejo, M.C.; Burbano, R.; Falconí, F.; Larrea, C. Leaving oil underground in Ecuador: The Yasuní-ITT initiative from a multi-criteria perspective. Ecol. Econ. 2015, 109, 175-185. [CrossRef]

102. Kolinjivadi, V.; Gamboa, G.; Adamowski, J.; Kosoy, N. Capabilities as justice: Analysing the acceptability of payments for ecosystem services (PES) through 'social multi-criteria evaluation'. Ecol. Econ. 2015, 118, 99-113. [CrossRef]

103. Cavallaro, F.; Ciraolo, L. A multicriteria approach to evaluate wind energy plants on an Italian island. Energy Policy 2005, 33, 235-244. [CrossRef]

104. Shmelev, S.E.; Rodríguez-Labajos, B. Dynamic multidimensional assessment of sustainability at the macro level: The case of Austria. Ecol. Econ. 2009, 68, 2560-2573. [CrossRef]

105. Hernández-González, Y.; Corral, S. An extended peer communities' knowledge sharing approach for environmental governance. Land Use Policy 2017, 63, 140-148. [CrossRef]

106. De Marchi, B.; Funtowicz, S.; Cascio, S.L.; Munda, G. Combining participative and institutional approaches with multicriteria evaluation. An empirical study for water issues in Troina, Sicily. Ecol. Econ. 2000, 34, 267-282. [CrossRef]

107. Gamboa, G.; Munda, G. The problem of windfarm location: A social multi-criteria evaluation framework. Energy Policy 2007, 35, 1564-1583. [CrossRef]

108. Russi, D. Social Multicriteria Evaluation and Reneweable Energy Policies. Ph.D. Dissertation, Universidad Autonóma de Barcelona, Bellaterra, Spain, 2007.

109. Lindborg, R.; Stenseke, M.; Cousins, S.A.; Bengtsson, J.; Berg, Å.; Gustafsson, T.; Sjödin, N.E.; Eriksson, O. Investigating biodiversity trajectories using scenarios-Lessons from two contrasting agricultural landscapes. J. Environ. Manag. 2009, 91, 499-508. [CrossRef] [PubMed]

110. Zasada, I. Multifunctional peri-urban agriculture-A review of societal demands and the provision of goods and services by farming. Land Use Policy 2011, 28, 639-648. [CrossRef] 
111. Garmendia, E.; Mariel, P.; Tamayo, I.; Aizpuru, I.; Zabaleta, A. Assessing the effect of alternative land uses in the provision of water resources: Evidence and policy implications from southern Europe. Land Use Policy 2012, 29, 761-770. [CrossRef]

112. Ruiz-Urrestarazu, E. Adaptación y gestión de medidas agroambientales y de forestación en el País Vasco. In Cambios en los Espacios Rurales Cantábricos tras la Integración de España en la U; Corbera, M., Ed.; Universidad de Cantabria: Santander, Spain, 1999.

113. Stirling, A. Analysis, participation and power: Justification and closure in participatory multi-criteria analysis. Land Use Policy 2006, 23, 95-107. [CrossRef]

(C) 2018 by the authors. Licensee MDPI, Basel, Switzerland. This article is an open access article distributed under the terms and conditions of the Creative Commons Attribution (CC BY) license (http:/ / creativecommons.org/licenses/by/4.0/). 